\title{
4
}

\section{The quest for identity}

\section{Turkish nationalism and Islam}

Turkey professes to be a secular state, the only such country in the Middle East and the only secular Muslim country in the world. Turkey is a living example, though not without difficulties, of a country whose population is predominantly Muslim but which is not a Muslim state. Ayse Kadioglu supplies a brief but painful enough reminder of the reforms, better called trauma, that the country and its population had experienced, which helps when evaluating the interaction between state and religion in Turkey, what has been achieved in this field, and the almost religious zeal - "secular fundamentalism" - in which secularism has been applied in the country:

The proclamation of the Republic in 1923 was followed by the abolition of the office of the caliphate in 1924. Other steps were taken in the course of the 1920s and early 1930s towards secularizing the Republic. These included the abolition of the Ministry of Religious Affairs and Pious Foundations, abolition of religious courts, proscription of male religious headgear, namely the $f e z$, dissolution of the dervish orders, reform of the calendar, and adoption of the Swiss Civil Code. By the end of the 1920s, radical reforms were passed such as dis-establishment of the state religion (10 April 1928), adoption of the Latin alphabet (1 November 1928), and the use of the Turkish language in the Islamic call to prayer (3 February 1932). These reforms constituted an onslaught on the existing cultural practices. They opted for a general state of amnesia, which would lead a process of estrangement of the people from some of their cultural practices. ${ }^{1}$

As Dogu Ergil writes, the disconnection of the Turkish society from its past allowed the ruling elite to see the people as an entity ready to be molded according to their vision of what society and the nation should be. ${ }^{2}$ Accordingly, separation from culture of the past was not confined to religious practices. In the pursuit for the unique Turkish nationalism (Milliyetcilik), different from the 
cultures and civilization in its proximity, Turkey severed ties with basic features of the Arab, Persian and Islamic worlds, emphasizing instead the modern and Western alternatives, as well as the pre-Islamic past. Hakan Yavuz mentions that during the 1930s and the 1940s villagers with traditional attire were not allowed to enter the major streets in Ankara, and were relegated to the less conspicuous back streets. ${ }^{3}$ A national narrative was supplied, in accordance with the rules mentioned above, that was to prove the uniqueness of the Turks, and their belonging to pre-Islamic and pre-Arab times. They are the descendants of the powerful Hittite Empire, whose capital was in Hatushash, near Ankara, and who, over the ages, made their way back to Anatolia from the prairies of Central Asia, the way shown to them by the Grey Wolf, the Bozkurt. ${ }^{4}$ (This last symbol, though indicating that ancient Turkic peoples emanated in much older times than Turkey's Islamic or Arab neighborhood, was later adopted by Turkey's PanTurkists. The Bozkurt thus acts contrary to the idea of Turkish nationalism which centers on the Turkish State alone; see pp. 109-110.) The Antatolian peasantry, of whom the Ottoman elite did not think very highly, was now, in the Turkish Republic, praised as the pure core of the Turkish nation. Dogu Ergil supplies a fascinating description of the efforts to supply an alternative Turkish ideology to the so-called defunct past:

In the absence of a medieval high culture that could be labeled "Turkish", the nationalist elite found their glory in a history that never was. The search for, and consolidation of, a new national identity were carried to such extremes in the 1930s that theories like the Sun Theory of Language were concocted. According to this "theory", all languages emerged out of Turkish. As a reminder of those days, the presidential banner consists of a sun representing the Turkish Republic encircled by 16 stars, symbolizing the Turkish states that were presumably created by Turks throughout history. This fabricated glorious past was a panacea for Turkish pride wounded by the loss of empire and reincarnated as a poor, backward society that was occupied during the First World War. ${ }^{5}$

True, in the fervent desire to break with the past, sometimes resulting in painful situations, secularism and modernization should be credited with great accomplishments, mainly in the urban centers. Turkey could honestly claim to be the only country in the Middle East, indeed the world, with a predominantly Muslim population that is not an Islamic state. But Turkish realities are not monolithic. Many Turks have never really separated themselves - openly or covertly - from their Islamic cultural heritage, nor from Islam's religious practices. Many Turks consider Islam as the powerful counter-identity to the totality that Kemalists have applied in Turkey.

The state, its Western and secular establishments and elite, view Muslim manifestations as detrimental to the very existence of modern Turkey. Indeed, the growth of Muslim influence in Turkey cannot be downplayed. The 1970s and the first half of the 1980s were years of economic crisis in Turkey, stemming mostly from the global energy crisis but also from internal Turkish phenomena like the huge wave of immigrants from rural areas into Turkey's urban centers. 
Those years subjected Turkey to acute inflation, shortages, unemployment, enormous expenditure on energy imports, and a slowdown in the absorption of Turkish workers in European countries similarly suffering from a recession. These difficulties, together with widespread existing feelings of being powerless, marginalized and excluded, in short belonging to the "have nots," contributed to the rising power of radical ideologies - rightist, leftist, national and religious - and of Islam in Turkey.

Outwardly, more Turks appear to fast during Ramadan, more to attend Friday prayers in the mosques, and more women to wear veils. A 1997 survey on sects, communities, shari' $a$ and foundations carried out in Turkey's major cities, reveals that 50 percent of the urban sector have religious morals and practice the necessities of Islam periodically. Thirty percent practice them every day. Though identifying themselves as religious, 16 percent do not practice the necessities of Islam. ${ }^{6}$ No doubt findings pertaining to the rural sector would give much higher figures.

The struggle between Turkish nationalism, secularism, and Islam; between western modernity and traditional structure, appears to be gaining momentum. Turkey is probably more Western than modern, i.e. the country adopted Western styles without simultaneously changing or promoting its laws, freedoms, rights, etc. Turkish nationalism was the last to be extricated, molded and refined from the ethnic hodgepodge that characterized the Ottoman Empire. ("Since they saw themselves the owners of the Empire, no one expected them [the Turks] to claim the right of self-determination. The Serbs left first, then the Greeks, the Bulgarians and Armenians, and only the Jews had no option". ${ }^{7}$ Practically a novice, Turkish nationalism had to face Islam, a well-established force, which is seen as a means for uniting all its followers and eliminating differences between them, i.e. between Turkey and its Muslim and Arab brethren, between Turkey and Islamic universalism or pan-Arabism.

Most scholars agree that although Turkish Islam shares many common features with other Middle East and Muslim movements, it has grown and developed in a very different political and social environment, shaping its unique nature. Turkey's Muslim ideology is tied up with Turkish nationalism in a unique fashion, because nationalism affected all spheres of life in contemporary Turkey. Religion and socialism - to name but two although far apart from each other - were among schools of thought and ideologies that were affected by Turkish nationalism. Still, there are Muslim Turks - they prefer to be called Turkish Muslims - who, although colored by patriotism, do challenge the secularist component and European identification of their society and of their country's Kemalist nationalism. These people question the intentions of the Turkish state when it comes to religious freedoms. Mete Tuncay, a leading Turkish intellectual, asserts that Turkish secularism does not mean a separation of politics from religion, but that religion is controlled by the state. The goal is to establish a kind of control mechanism to prevent religion from influencing politics. ${ }^{8}$

One milestone in the rise of Islam in Turkey was the officers' coup of 1980, in whose wake religious lessons were made compulsory in schools. The army 
justified its intervention in domestic politics by pointing to the growth of the radical and Marxist left, particularly its militant and terrorist elements. The encouragement of "bearable" religious believers and of religious education in schools was considered by the army to be the antidote for the impact of ethnic extremism and the Iranian revolution, as well as leftist radicalism. "Islam's green will defeat communist red," was the mantra. Considered a factor of unity, Islam was thought to be the remedy for many divisions in Turkey, among them the Turkish-Kurdish conflict. The result: "Islam had finally been brought from the periphery to the centre of Turkish politics." Simultaneously though, all through the 1990s, the Turkish military dismissed hundreds of officers and non-commissioned officers (NCO) for being "excessively affiliated" with Islamic bodies. On 16 June 1998, for instance, 167 officers and NCOs were fired in the largest purge carried out in a single day. ${ }^{10}$

When Turkey reverted to a multiparty system in 1983, the Muslim opposition groups came to occupy a legitimate slot in the political system. People from the lower classes and many Kurds joined Islamic opposition parties because the existing parties did not address their needs. Furthermore, some of the opposition to the establishment, having failed to find its place in the political mainstream, was also drawn to the Muslim parties. In the 1995 general elections, for instance, in the western urban centers, the mostly Kurdish shantytowns voted overwhelmingly for the Welfare Party. ${ }^{11}$ The poor attitude towards Turkish immigrants in Europe also contributed to their anti-Western and European feelings, which soon enough were expressed in Muslim extremism or a return to their old ethnic roots (i.e. Kurdishness). Political parties courted Muslim circles and granted them religious concessions in return for their votes. This may well explain the appearance of certain previously banned practices, such as calls to prayer in Arabic, Muslim publications, Muslim schools, and Muslim associations.

The Muslim parties gained ground in both general and local elections. In the December 1995 general elections, Muslim parties received about 21 percent of the vote, 2 percent more than in the March 1994 local elections. In the last three general elections, the Muslim parties have tripled their strength. Twentyeight of Turkey's seventy-six city councils, including Istanbul, Ankara and Izmir, are ruled by representatives of Muslim parties. The result of the general elections in December 1995 showed the Refah Partis, the Welfare Party, to be the largest party in Turkey -21.2 percent. In short, a formerly marginal political element, which lacked legitimacy, found itself accepted into the political establishment. ${ }^{12}$

The resurgence of Islam in Turkey could also be linked to the growing prominence of Muslim oil-producing countries such as Libya, Saudi Arabia and Iran. Turkey's dependence on energy imported from them in the 1970s, and their accumulated purchasing and investment power, induced the Turkish government to moderate its attitude towards Muslim circles (and to scale-down its relations with Israel - see Chapter 7). Similarly, the previously banned Arabic script, became increasingly evident in Turkish commercial areas, something that could be attributed to the affluent of the Arab world which, having been 
deprived of Beirut as a place of entertainment, shopping and investment, took to Istanbul as one possible substitute. ${ }^{13}$

But above and beyond the political events noted here, ideological, economic and social motives came into play in the rise of Islam in Turkey. The crisis of communism throughout the world and the repression of the Turkish left channeled many marginal or extreme groups to another radical alternative-Islam. When growing portions of the population fail to ameliorate their lot through modernization, the answer to inflation, unemployment, uncontrolled urbanization and exorbitant real estate costs, slums and alienation, is Islam. Islam seemed to offer a third way: neither capitalism nor socialism. It is a response akin to the response of the world's poorer peoples to secularization, the collapse of communism, Western materialism, capitalism, globalization, and the intrusion - even imposition - of alien, principally Western, cultures. It is a search for identity on the part of people whose rulers have adhered to the West and its values to an excessive degree, while they themselves find Western luxuries unattainable.

The Muslim revival is doubly powerful when Muslim organizations and political bodies move in to take the place of enfeebled and impotent government. It should be noted that some 1,500 new mosques are constructed annually. Altogether there are more than 80,000 mosques in Turkey - a mosque for every 800 people - some of which clearly indicating the strength of religious defiance visà-vis secular Kemalism. See, for instance, the monumental Kocatepe Mosque in Ankara that overlooks Anitkabir, Ataturk's mausoleum and burial ground. But apart from soul saving, Muslim bodies also provide education, health services, housing, and employment. Islamic banks offer interest-free loans, as Muslim law dictates. Muslim groups allocate food and money to the poor. Millions of poor migrants, many of them of Kurdish origin, who were forced to leave the war torn areas of southeast Turkey, looked for sustenance from these Muslim bodies. This support was not granted to them by Turkey's secular parties. Above all, a common religious solidarity and a sense of belonging - so important for uprooted people - was provided for them by the Islamic Refah Partisi. ${ }^{14}$

Does all this constitute a threat to Turkey's unique status in the surrounding Arab and Muslim worlds, to its links with the West, to its aspirations for Europeanization, to Turkish democracy? There is no single answer to these questions. Those concerned for Turkey's image in view of the Muslim revival are worried mainly over the failure of the state in the social and economic domains, and its replacement by Islamic organizations. The price of public welfare, when carried out by religious or even fundamentalist circles instead of the government, is exploitation of the misery of the masses - particularly migrant villagers and Kurds uprooted from their home provinces. Since the outbreak of the PKK rebellion in 1984, some 3 million Kurds have relocated from the southeast of the country to its western provinces. As a consequence, 3 million Kurdish residents have transformed Istanbul into the world's largest Kurdish city. Adana, too, is now a Kurdish city, so is half of Izmir. The unfortunate people receiving handouts are told that Western progress is to blame for their troubles, and that Islam 
will better their lot. When the beneficiaries expressed their gratitude in the polling booths by awarding their votes to the Islamic parties, they altered the political balance in Turkey's municipalities, and doubly so at the national governmental level.

Some grave consequences have followed upon this trend. Wherever the Muslims were triumphant, hostels for battered women were closed. In a number of places restaurants serving alcohol were shut down. Efforts were made to segregate men and women on public transport, and Muslim mayors have made such changes as painting all the bus stations green, the color of Islam. Banning was imposed on immodest advertising in posters and films, and in public there was insistence on modest attire. Municipal offices were closed early during Ramadan, and there were reports of intimidation of people who did not observe the fast. In the past, Turkish courts opposed closing early during Ramadan. Similarly, time off for workers for Friday noon prayers was not granted because the official day off is Sunday. Classical music and ballet are under attack as symbols of decadent Western culture. Neither are the city walls of Istanbul spared: it is said that Muslim extremists want them demolished, as they are a symbol of the Byzantine Christian regime that preceded the Muslim Ottomans. ${ }^{15}$

Conversely, there are those who see no threat in the Muslim revival and its expression in Turkey's cities - the countryside is traditionally devout - even going so far as to predict a reduction in recruitment to Islam. Admittedly, Islam is more evident on city streets - women wear veils, men are bearded, long rows of worshipers prostrate themselves at prayer, Muslim charities and businesses and grassroots organizations of the Muslim parties are active everywhere. And everything is so discernible. As Nulifer Gole put it: "instead of asking for assimilation and equality the Islamists claim differences, much as U.S. Afro-Americans have done ... 'Islam is beautiful like black is beautiful."'16 But this might also be misleading, or could be differently interpreted. Most of these believers are migrants from the traditionally religious villages. The construction of transportation and communication networks has eased this migration, which was part of the mighty wave of industrialization and urbanization that has swept Turkey since the 1950s. During the past two decades, cities with over 100,000 inhabitants have increased their populations to 9.3 million, while places with a population of 2,000 or less have decreased by 1.6 million. To give but one example from the research of Resat Kasaba and Sibel Bozdogan: in 1927, 12.5 percent of the Turks lived in cities with over 20,000 inhabitants, whereas in the year 2000, 71 percent of Turkey's population is classified as urban. ${ }^{17}$ The argument therefore goes that the numbers of the faithful have not increased, they have merely relocated from countryside to city, thus become more visible. Furthermore, urbanization holds out prospects of moderating the rise of Turkish Islam. The number of villagers who pray at least once a day stands at about 70 percent; the number drops dramatically to 24 percent in the cities. Dwindling numbers of city-dwellers fast at Ramadan, and attendance in the mosques is smaller than in any other Muslim country. In other words, the villager's exposure to urban culture is liable to temper his or her 
Muslim fervor, for past experience shows that today's city-dweller - yesterday's villager - is less drawn to Islam and its attractions. ${ }^{18}$

A review of the history and nature of political Islam in Turkey - for example, the rise to power of the Welfare Party under Necmettin Erbakan and its brief tenure there - reveals that the threat the Islamic parties posed to Turkey's identity was significantly less than the authorities feared. There was a huge difference between Turkey's Islamic parties and the radical militant Muslim parties of Iran and Algeria, and it is not by chance that Turkey is rarely mentioned in surveys discussing Middle East religious fundamentalism. Only a minority among Turkish Muslim believers consider Islam and its universal aspects to be superior to their country's nationalism and patriotism. A brand of political TurkishMuslim synthesis exists which emphasizes the national needs of the country (for instance: the right-wing Nationalist Action Party, led by Alparslan Turkes; see p. 110).

Erbakan's short-lived regime - from June 1996 to June 1997 - failed to allow one to draw clear-cut conclusions about the nature of Muslim politics in Turkey. They made no changes in foreign policy - neither withdrawing from NATO, nor severing ties with "the microbes of the Zionist banking system" - neither did they try to put engulfing internal Muslim reforms into effect. For example, nothing materialized from Erbakan's promise to build a mosque at the center of Istanbul, in Taksim Square, across from the Ataturk Cultural Center, an icon of secular Turkey, or in Cankaya, the section of Ankara where the presidential palace is located. ${ }^{20} \mathrm{~A}$ similar fate awaited the proposal to allow women government employees who wanted to attend work wearing head coverings, or - unlike in municipal offices - for shorter working hours during Ramadan for government employees who obey the fast. As Philip Robins observed, the government was considered by most to be a continuation of the previous one. Being in opposition Erbakan spoke loudly against Turkey supporting US bombings in north Iraq, and Turkey called it "a second Sevres," and was extremely critical of Ankara's contacts with Israel. But, once in power, he concurred -often reluctantly or retrospectively, when it was found that he had been ignored - with these very Turkish moves. ${ }^{21}$

In June 1997, Erbakan was forced to step down under pressure from the military. The reasons given were that the policies and actions of his government were not commensurate with the principles of the constitution with regard to democracy and secularity. It was not the first time Erbakan had fallen foul of the army, which had already dissolved two of his political creations, and both times after launching a coup. In 1970 the Generals had disbanded the Islamic National Order Party and, in 1980, the National Salvation Party. Rather than risk a third coup and see the Welfare Party go the way of its predecessors, Erbakan chose to play by the rules of, the albeit very Turkish, democracy, and resign. He was to be sorely disillusioned. In January 1998 Turkey's Constitutional Court declared the Welfare Party illegal on the grounds that its platform and polices contradicted Turkey's secular constitution - from the time the court was established in 1963 
until 1998, it had dissolved twenty parties for these reasons. It was the third party led by Erbakan to be dispersed and Erbakan himself was excluded from all political activity.

Eleven months of Muslim rule, 1996-97, had made it clear that "Turkishness" and Turkish democracy were still more vital than any Muslim principle. It is interesting to note that 41 percent of the voters for the Muslim Welfare Party defined themselves as secular and considered Ataturk, not Mohammed, their most important historical figure. Nor is Jihad - Holy War - considered a practical method for achieving any of the aims of the party program. ${ }^{22}$ Disagreements do exist, and they are painful as the following words show, but they are not carried to excess. For instance, Erbakan protested that "If I make a speech and say this is what our dear Prophet Muhammad said, they will start banging on the desks and protesting. This is not secularism, it is enmity toward religion." ${ }^{23}$ Similarly bitter was Abdullah Gul, member of the Refah and a former Minister of State: “They want to create another religion, which is atheism. It's the secular people who are not tolerant, and they want to impose their lifestyle here." ${ }^{24}$ The struggle, even conflict, between Turkey's secularity and Islam goes on, but it does not appear as extreme as the Iranian or Algerian models. A devout Muslim headed the government in Ankara; a no less devout Muslim Prime Minister relinquished this post, his party later to be declared illegal. There was no trace of Erbakan's vow to pursue his policy "with or without blood." ${ }^{25}$ All was done democratically, admittedly Turkish democracy.

The little that Erbakan did on foreign policy was no more impressive. Perhaps he did not have enough time. Nothing of "Islamic fraternity" came out of his much publicized visits to Iran, Malaysia, Algeria and Libya. Interestingly, Erbakan likened his return from Tripoli to no less than the homecoming of a victorious Roman tribune. In Tehran he clearly failed to contain the Kurdish issue on the basis of Muslim brotherhood; Iran has not stopped granting facilities to the PKK. ${ }^{26}$ Similarly, nothing substantive emerged out of the November 1996 twenty Muslim countries conference that Erbakan had organized. Neither was the D-8 bloc, launched in Istanbul in 1997, any more of a success. The idea was to promote trade and economic cooperation among the 800 million combined populations of the eight Muslim developing countries. Turkey, Egypt, Iran, Nigeria, Pakistan, Bangladesh, Malaysia, and Indonesia account for 4 percent of world trade, but with whom Turkey's trade is less than 4 percent of its total foreign trade. Why, then, not changing the picture by calling on the Muslim countries to abandon the American dollar as the basis of trade and increase mutual trade from the 10 percent of today to 90 percent in the future? The Refah party, it should be recalled, vigorously opposed Turkey's accession to the EU - the custom agreement signed with Turkey was "Frankenstein's poison." Accordingly, the colonial, unjust, oppressive, Christian West was not an option, let alone that it is inferior. On a trip to Kuala Lumpur, in August 1996, Erbakan declared that Western development has been dependent on Islamic intellectual contributions - Arab arithmetic, for example - and that Western scientific 
progress is hindered by belief in the Trinity. "Many think he is often unable to distinguish between fantasy and reality," commented Morton Abramowitz, Washington's former ambassador to Ankara. ${ }^{27}$

As Atila Eralp summed up, the West, the EU in particular, being a Christian community organized to undermine the Muslim world, the pro-EU lobby in Turkey being a part of a Zionist plot to sow dissent among Muslim countries this was the world of Erbakan. ${ }^{28}$ Obviously, nothing of Erbakan's "Islamic openings," "Islamic automobile," or "Islamic aircraft" materialized or brought gains to Turkey. On the contrary: "Eleven months after his [Erbakan's] accession to power, Turkey's relations with most other Muslim states were worse than before," concluded Andrew Mango. ${ }^{29}$

Even Erbakan's signature on a twenty-five year, 23 billion dollar agreement, for the annual supply of close to 10 billion cubic meters of Iranian gas to Turkey, was actually the final step in a long-term process, that started before the Refah came to power. The Iranian project was on the agenda of the two foreign ministries since 1995, when Turkey had decided to diversify its energy sources, and to use imported natural gas instead of the local low-grade coal. The Ankara example encouraged Turkey to continue the use of natural gas. The conversion in Ankara to natural gas has finally made the air in the capital fit to breathe. The projected pipeline for Iranian gas is therefore meant to serve Erzurum, Sivas, Kayseri and Konya - all grim towns enveloped in smog in the harsh winter weather. ${ }^{30}$ The entire deal consists of 228 billion cubic meters of gas. If both sides completed their obligations and each constructed on his side the necessary facilities, the first transport of Iranian gas was to reach Ankara by 1 August 2001. Next to Russia (more than 30 percent), Iran (12 percent) will thus become Turkey's biggest gas supplier - until the gas deal with Turkmenistan materializes (see p. 127). However, this dependency raised much concern, particularly in Washington, as to the leverage Tehran could use against Turkey.

Turkey's energy needs are increasing quickly; the country is the fastest growing gas market in Europe. Its gas demands during the 1990s have been growing at 10 percent a year, and by the year 2005 it is expected to have quadrupled to 45 billion cubic meters, and more than 80 billion meters by 2020 . Oil needs are similarly urgent: the country produces about 3 million tons of crude, which is a mere 13 percent of its consumption, the rest being imported. Iran, Saudi Arabia, Syria, Iraq, and Egypt are Turkey's oil market and the country constantly diversifies its supply sources. The forecast is for close to 50 million tons of oil imports by the year 2010, 40 percent of it from the Caspian region and Russia. Hence, if power cuts and gaps are to be avoided a decade or two from now, proper planning and large investment are needed in the energy market. It is estimated that Turkey will need to triple its total generating capacity by 2015 to meet rising demand - from today's 27,000 megawatts to more than 85,000 megawatts. The country's consumption of oil, gas, coal, hydro-energy, etc. for the production of energy, currently equals to 71 million ton of crude oil 41 percent oil, 16 percent gas, 30 percent coal - might increase to 300 million 
tons by the year 2020. It will then consist of 27 percent oil, 29 percent gas and 32 percent coal. ${ }^{31}$

As mentioned above, Erbakan was forced to step down under pressure from the military. The Generals accused the civil echelons of ignoring excessive religious activities and of failing to impose the secular articles of the Constitution. The army demanded on 28 February 1997 that Erbakan order a number of reforms to restrict what was perceived as religious fanaticism and Muslim extremist politics. After he balked at implementing these demands, Erbakan tendered his resignation in early June 1997. With Turkey facing a conflict between its first Muslim Prime Minister and the military, the scenario of the Gulf War did not repeat itself: in the summer of 1997 resignations were handed by the politicians, not by the Generals.

Among other things, the Prime Minister was asked to reinstate Section 163 of the political penal code - the section had been annulled in 1991 - which prohibits religious political activity that is a threat to the secular state. Accordingly, new laws were to be enacted that would restrict such detrimental activity. The army insisted on a uniform secular education for all and a limit to the number of Muslim-sponsored schools' graduates who would be admitted into the cadres of the civil service. A great deal of attention and demands for cuts were focused on the government-controlled Directorate of Religious Affairs, with a 350 million dollar budget - exceeding that of five combined ministries ${ }^{32}$ - which has expanded from 50,000 staff in the 1970 s to 100,000 in the 1990 s. The Directorate is responsible for the country's 80,000 mosques, 600 religious high schools, 4,000 religious courses and 24 college-level programs that turn out Turkey's future Islamic scholars and imams. ${ }^{33}$ Other demands related to a reduction in the number of theological seminaries and prohibition of anti-secular broadcasts in the Turkish media. An insistence worth noting was for a ban on sales of skins from animal sacrifices in the Muslim holiday Eid al-Adha, or the Feast of the Sacrifice, called Kurban Bayram in Turkey, marking the end of the Haj, the Pilgrimage to Mecca. The intention was "to kill these Islamic groups in their embryonic stage, and it starts with [the proceeds from] sheepskins." ${ }^{34}$ This prohibition - on the books for a long time - has until recently been widely ignored. The Turkish Justice Ministry announced that it would prosecute and insist on six-month prison punishment for those who illegally trade in sheepskins, one of the products of the Bayram slaughter. Proceeds from the skins used to go to religious groups and to Muslim parties, though the government encouraged it to be donated to secular or military bodies. ${ }^{35}$

During his year in office Erbakan's government was cited for “incompetence and lack of preparation for running Turkey." ${ }^{36}$ Furthermore, a number of bribery scandals were uncovered which cast a long shadow over the Refah's integrity. However, the Refah, was outlawed in January 1998, and succeeded by the Fazilet, the Virtue Party. The new body acted under the remote control of Erbakan, probably the reason why it did not do so well - it achieved 15 percent of the votes - in the April 1999 general elections. Expectations, it is worth 
noting, were much higher. In the mean time it seemed as if the successive increases of political Islam in Turkey were blocked; a political party of 15 percent does not seem too menacing.

International media, as well as Turkish public opinion, objected strenuously to the fact that it was the army that forced Erbakan out, violated Muslim religious freedoms, and brought about the dissolution of the Welfare Party. "A second Algeria" - a rather exaggerated terminology - was the example Turkey has been compared to. The Chicago Tribune pointed to a tragedy that looms over Turkey, referring to country's "arrogant" yet extremely strong military elite, who was launching war against, no less, student girls wearing the headscarf, the hijab, known in Turkey as "Turban," even when worn by women. A government decree from February 1998 barred university students from class for wearing Islamic dress; university rectors and presidents followed suit and ordered the ban enforced. On 10 June 1998, Turkish police and Muslim students scuffled in Istanbul University following the university's refusal to allow eleven female students wearing head coverings to take final examinations. ${ }^{37}$

The official explanation for the imposition of the headscarf ban in Turkish universities is that students' dress codes require Western-style clothes. Defying it by wearing the hijab was a symbol of political Islam, a matter threatening the Constitution's articles that decree Turkey is a secular state. Yielding to the hijab seemed to spokesmen from the Turkish middle class as the beginning of an irreversible process in which Turkey would become a Muslim republic. The secular republic was not going to survive this "political cancer," so they would warn. Turkish political Islam presses continuously for the Islamization of Turkey, including issues such as sex relations, family concepts, dress codes, private and public divisions, science, government and the rule of law. Hence, wearing the hijab is not a cry for democracy or for the preservation of human or feminist rights, but is the battlecry of Turkish political Islam. Granting a concession today, allowing females to wear head-coverings or students to be bearded - the ban on both has been on the books for a long time but is widely ignored - and tomorrow "they will not hesitate to force us all to cover ourselves, if they get a chance."38

All the above are senseless and do not exist at all, maintain the Muslim parties. There is no enforcement of Muslim values on women's attire, on education, or on law, and there is total revulsion towards all sorts of religious violence. They distance themselves from acts of terrorism such the horrific events of 1993, when militant Sunni activists set fire to the Madimak Hotel, in which an Alawite convention was being held, killing thirty-seven people. They proudly point to Demokrasi, Insan Haklari, Ozgurlu (Democracy, Human Rights, Freedom) as the principles that top the parties' agendas. Accordingly, Turkish political Islam is seeking to produce a balance between Western values and Muslim tradition, aiming at a state where the "Islamic headscarf and the miniskirt walk together hand in hand." ${ }^{39}$

It was education, however, that proved the most hotly contested battleground between Turkey's secular authorities and religious circles. The education system plays a crucial role in shaping Turkey's identity. Determining 
children's minds, education could ultimately be the deciding factor as to whether secularism or religion win the day. Elementary education in Turkey has been compulsory since the 1950s. Still, quarter of the children do not attend primary school, and the average number of years spent in the classrooms was 3.6 years or, in the case of girls, 2.4 years. ${ }^{40}$ According to research by the World Bank, by allocating 240 million dollars to education - 1.5 percent of its GNP - Turkey was, in 1995, on a par with Ethiopia. In practice it meant that Turkey's classrooms were vastly overcrowded, with fifty-five pupils per class, double the number in the West, and understaffed. Many teachers must moonlight.

The eight-year, replacing the old five-year, compulsory education law, was enacted in Turkey in 1998 by the government of Mesut Yilmaz. It aroused much protest from religious circles. The latter claimed that the law was aimed at preventing children from being influenced at an early age by religious education at the Imam Hatip schools, originally founded in 1951 for the purpose of training imams for the mosques. By the 1990s, the Imam Hatip schools were producing, annually, 53,000 diploma-qualified religious preachers. It was far more than Turkey's mosques annual requirement of 2,300 imams.

According to the new education law, the junior sections of the religious schools were to close down. Only the high school sections of the Imam Hatip schools were to remain open. The state primary school system was to be extended from five to eight years; however, even before this legal extension, most of Turkey's 15 million students attending state schools used to stay on for eight years in various modes of private, public and religious education. Another cause for much controversy were the Koran schools active in local mosques, which many primary school children attend in their spare time and holidays. Between the 1980s and the 1990s the number of these schools doubled to 4,700 and attendance reached 155,000 . According to the new law, children now are only allowed to attend the Koran courses after graduating from the eight-year compulsory education. ${ }^{41}$

Before the enactment of the law, on terminating the five-year study, 500,000 pupils continued their studies at some 600 religious schools for an additional three- to seven-year period. And though the main wrath against the religious school system was during the Prime Ministry of Erbakan, it is interesting to note that his term of office was the only period with no increase in the number of religious schools. In 1951 Turkey had a mere seven religious schools attended by a miniscule number of pupils. In 1975 there were 150,000 pupils; in 1995 there were 479,000 pupils who attended 448 schools; and by 1996 there were 561 such schools boasting 493,000 students. ${ }^{42}$

In the 1997-98 education year, the Turkish Ministry of Education, in line with the Talim Terbiye Kurulu's (Training and Education Council's) recommendation, banned twenty-six textbooks, which, it claimed, espoused "reactionary propaganda", a typical euphemism denoting religious fundamentalism or politicized Islam. ${ }^{43}$ Various changes were made in the remaining textbooks to be used during the eight-year compulsory education and in high schools. Philosophy became a compulsory class on the grounds that it teaches students to 
develop skills of "thinking and discussing." Social and political issues were added, among them topics related to the EU, human rights, traffic education, and environmental and health issues like AIDS, and organ transplants. National security classes were incorporated in high school curricula. The Turkish armed forces and their vital importance to the country's well-being and in defending principles of democracy, prosperity and secularism, is a subject that has recently been introduced. Conversely, there is also a course on "Fundamentalist Reactionarism," which explains "why some do not want Turkey to develop and become modern." ${ }^{44}$

It is much too early to judge whether the government's education reforms were successful, allowing the secular state to regain its hold over Turkey's youth. It will take a great deal of time and money, particularly in view of the dismal state of Turkey's education system, before these reforms, extensive and expensive, can take effect. Unfortunately, owing to the economic crisis of 1999-2000, and the violent earthquakes which hit Turkey in August 1999, not much money was available to devote to the education system. It is also extremely unlikely that the religious establishment will abandon its grip on Turkey's children without a fight. At present, the state has the upper hand, but only time will tell who finally wins the battle for the minds of Turkey's youth.

One observer, Richard Tapper, regarded the Muslim revival in Turkey, which began in the 1970s and 1980s, as a rebuke to those who predicted that modernization, education, progress and urbanization would lead to moderation of the Muslim character of Turkey. It seems, however, that at present Islam in Turkey is a culture of protest, a unique product of Turkey, not a recipe for revolution that harbors non-Turkish goals. Its political features, the Repha Partisi, for instance, have integrated into the Turkish pluralist system, and do not plot against Turkey's very democracy, toward an ultimate goal of installing a religious-based pan-Islamic regime in the country. Even if looking forward to vanquishing the West through a blend of Turkism and Islam, the Muslim revival has yet to advocate the notion of a Turkish nation state for fear of angering opponents, particularly in the army. A not inconsiderable degree of political pluralism and separation of religion from state has taken firm root in Turkish society. Accordingly, the gains of the Turkish Muslim movements are clearly visible - in the year 1994, 700 of the 1,600 key ministry executives, provincial governors and other functionaries were believed to be Refah supporters. The party's main activity focused on the urban poor, where it furnished them with services and commodities that the government failed to supply. Still, the Refah opted for caution, for struggle within the parliamentary system, desisting from a direct clash with Kemalism, defended by the Turkish military. It is worth noting that Turkish Muslim terrorists avoid attacking military or security personnel, but instead aim at secular intellectuals, media people, Jewish, American and Israeli targets. This clearly contrasts with Egypt or Algeria where police and army were preferred targets for religious radicalism. This says something about the deterrence of the Turkish military. It also shows that Turkish Islam does not consider itself 
as separate from the state and its organs, but sees itself equally Turkish as the military. The peaceful way in which the Refah and the Fazilet accepted their forced dissolution and the jailing if its leaders (during 1998-2001), shows that Turkish Muslim parties' threatening character should not be overrated. It is, perhaps, indicative that two detailed surveys of Middle Eastern Islamic radicalism hardly mention Turkey. ${ }^{45}$

Thus, at the onset of a new millenium, it appears that it is secular Turkey that is the lion and Islam the lamb in our story. True, the two may on rare occasions, as in a zoo, live peacefully side by side, with the proviso that "every now and then we have to replace the lamb." ${ }^{\prime 6}$

\section{Turkey and Iran: opposite ends of the pole}

Nationalism and Islam inevitably cause Turkey and Iran to cross each other's path and to hold perverse, if not painful, images each about the other. Iran, in particular, does not do much to assuage Turkey's suspicions. Tehran is thus perceived in Turkey as violently anti-Western, fanatically religious and intent on spreading its revolutionary message throughout the Muslim world, in short Kemalism's and Turkey's worst nightmare. Ceaselessly challenging, verbally and actively, Turkey's political, religious and social identity, constantly denouncing Ankara's traditional Western orientation, and vying for power and influence in Muslim Central Asia at Turkey's expense, it seemed that there was nowhere Turkey could turn without encountering Iran's grim, hostile face. Even in areas of presumable agreement, such as Iraq and Kurdish nationalism, Tehran pursued policies that flagrantly contradicted Turkey's interests. Though rivals, subjecting one another to a barrage of verbal abuse and intent on undermining each other's policies, and possibly sovereignty, Turkey and Iran have yet to come to blows, a puzzling state of affairs.

A secular, pro-Western democracy, representing everything Iran despises, Ankara was positive that Tehran sought to export the revolution to Turkey. Ankara knew that it would be an extraordinary coup for the revolution should Iran manage successfully to subvert Turkey, a key Muslim state, a symbol of profane worldly rule, as well as a strategic and ideological adversary. Regularly and violently, Iran raged against the Turkish secular state, against Turkish democracy, and against Turkey's blind adoption of Western values. Periodically, the two countries discover spy nets, expose terror cells, declare diplomats as persona non grata, etc. While Turkey blames Iran for supporting the PKK and acting against its secularism, democracy and Western values, Tehran suspects that Ankara, together with Azerbaijan, foments anti-Iranian feelings among the Iranian Azeris. Iranian dignitaries, while visiting Turkey, do not respect the Turkish flag or anthem, neither do they pay a visit to Ataturk mausoleum, a must on any visitor's itinerary. Ataturk, it should be recalled, was declared an "enemy of Islam" by Tehran. The refusal to bend down before the statute of 
Ataturk while laying a wreath at the tomb, as demanded by protocol, was explained as violating the Muslim prohibition against bowing down to an idol. This was adding insult to injury, by implying that Turkey was not only a secular state but an idolatrous one to boot. The daughter of President Rafsanjani of Iran, observed during a visit to Ankara (December 1996), that the situation there reminds her of the last days of the deposed Iranian shah. Turkish press reacted furiously, adding "Thank you Ataturk," and praised the modernization existing among Turkish women in the secular Republic of Turkey as against the backwardness of the Iranian Muslim revolution. ${ }^{47}$

But, for all its sniping, criticisms, and insults, Iran was not foolhardy enough to confront Turkey head on, preferring instead to rely on covert and indirect methods of action. Not that this stopped Ankara, which deeply resented Iran's poisonous tirades and was unnerved by what it suspected were Tehran's ultimate objectives, of accusing Iran of meddling in Turkey's internal affairs, of subverting its population, of supporting anti-government terrorists, and launching clandestine operations, all in order to undermine the Turkish regime. In 1993, the celebrated intellectual and journalist - famous for his investigations into the drug trade as well as his exposé on the attempt on Pope John Paul's life, Ugur Mumcu, who was also one of the more outspoken supporters of Turkish secularism, was murdered. Ankara claimed that it was Iranians, or Turks trained by the Iranian intelligence service, who were responsible for this damnable deed. In May 2000, the Turkish police arrested some 300 Iranians for involvement in various terrorist actions, among them members of the Al Kouds (Jerusalem) terrorist organization, which had murdered Israelis, Americans, as well as Turks opposed to Turkey's apparent drift towards Islam. Ankara bitterly complained about Iranian declarations in favor of applying the Muslim shari'a law in Turkey, or against Ankara cooperating with the United States and Israel, or being a member in NATO. In February 1997, the Iranian ambassador to Ankara, Mohhamad Reza Bageri, threatened Turkey with God's punishment following its cooperation with Washington and Israel. These Turkish contacts, alleged Tehran, place Israel and the United States - both branded in Iran as the little and big Satans, respectively - as her immediate neighbors.

Turkey also accused Iran of actively supporting Turkish terrorist groups, including the Turkish Hizbullah, known as the Islamic Movement or Islami Hareket. According to the MIT, Turkey's National Intelligence Organization, Iranian diplomats hunted out and recruited pro-Islamic sympathizers, while the Iranian cultural centers were used to indoctrinate and subvert impressionable young Turks. The more malleable and radical youths were sent to Iran, where they were brainwashed and trained in military and terrorist tactics. Furnished with real and forged documents, and armed with weapons and explosives, they were returned to Turkey with orders to carry out terrorist attacks against Turkish citizens and leaders of the Iranian opposition. One million Iranians had fled the terrors of Khomeini's Iran into Turkey and, according to Turkey, the Iranian 
secret service was directly implicated in the assassination of several of the more prominent of these Iranian refugees. ${ }^{48}$

Turkish-Iranian relations revolve around a series of issues. The two share common views as to the preservation of Iraqi integrity - though Iran protests over the Turkish army incursions into northern Iraq, regarding them as attempts to seek changes in the borders. Both countries share objection to Russian growing influence in Central Asia. Moscow, however, sees Iran as a balancing factor that moderates the influence of Turkey in the Caucasus and Central Asia. Both Iran and Turkey reveal objections to a Kurdish state, and Tehran does not fail to see the detrimental effect that realization of Kurdish national aspirations elsewhere might have on its own Kurdish or Azeri communities.

Ankara, however, resents the Iranian influence in the Caucasian Muslim republics and the improvement in Tehran's relations with the Gulf States - like the political dialogue with Saudi Arabia and the resumption of flights between Riyadh and Tehran. Turkey is also concerned because of the development of ballistic and probably nuclear capability by Iran. Iran, though, accused Turkey, together with the United States and Israel, of organizing the mass demonstrations that swept Iranian cities in 1999, protesting against the clerical regime in Tehran. Prime Minister Ecevit labeled the demonstrations a "natural" reaction against an "outdated regime of oppression." ${ }^{4}$

Strangely, economics not religion, proved the main battleground between Turkey and Iran in Central Asia. Ethnically, Iran had little in common with the primarily Turkic nations of Central Asia. Moreover, the latter, mostly Sunni Muslims by faith, tended to firmly reject Shi'ite interpretations of Islam and were hardly susceptible to the preaching of Shi' ite Iran. The Republics' ruling elites were determined to preserve their countries' secular identity and embraced steadfast anti-Islamic policies. As a result, other than in Tajikistan, which is ethnically akin to Iran and whose Tajik language bares a close resemblance to Pharsi, Iran's attempts to disseminate its revolutionary Islamic message throughout Central Asia failed. Even in Tajikistan, which publicly displayed photographs of Khomeini, it was essentially the ruling elite's fear of being submerged by the Turkic majority of Central Asia that drew it closer to Iran. Seeking Tehran's protection, the Tajik authorities adopted the principals of the Iranian revolution. Not everyone in Tajikistan was happy with the regime's Islamization and the result was a vicious civil war. Nevertheless, there was always the possibility that Iran would exploit the Islamic issue, to stir up the people of Central Asia, who, straining under the burden of backward economies, corrupt regimes, and few social amenities, were highly susceptible to radical religious messages. The last thing Turkey wanted was a series of radical Islamic republics on its doorstep. Accordingly, constantly on guard, it offering the Republics' secular regimes all the help it could to combat any sign of an Islamic revival. Turkey expected that the secular ideologies and the secular political systems left in Central Asia by the Soviets would continue well into the post-Moscow era. Therefore, Ankara was even willing to acquiesce in the presence of its great rival for 
regional primacy, Russia, in the area, aware that Moscow was much better placed than it to combat the perils of Islam. ${ }^{50}$

However, it was the Republics' economic potential that formed the focus of Iran's and Turkey's rivalry in the region. Ankara hoped to exploit its links with the Republics to become "a crossroads" between East and West, with goods shuttling back and forth between the Far East, the Republics, Europe and the United States across Turkish territory, to the benefit of the Turkish economy. It was a position that Iran threatened to usurp. Iran, like Turkey, had century-old contacts in the region, which it could and did turn to its economic advantage, often at Turkey's expense. The newly built railway lines between the Republics and Iranian ports, completed in 1996, which not only carried 1 million passengers and 8 million tons of cargo annually, but also reduced the transport time between Europe and southeast Asia to less than ten days, presents a very attractive and cheaper alternative to the Turkish land route. Iran, not Turkey, might turn into the "crossroads" where East meets West.

The choosing of national languages spoken by the majority in the Central Asian republics is of importance to our discussion. During the Soviet era, national languages, as well as the Turkic common heritage and kinship, were wittingly neglected because heterogeneity of languages was considered detrimental to Soviet unity. Instead, the Russian language has played a role in the Russian dominance and in binding the republics together. During the Soviet era almost every education or science institution was using the Russian language. Even today, Russian is still needed in practically every sphere of life. Cleansing the language of Slavic and Russian words, replacement of Cyrillic letters by Latinization of the language, not by Arabic scripts - these are symbols of nation building and of disconnection from the Russians and separation from the Iranians. The shift to Latin characters, not to the Arabic alphabet, brought about protests from Iran and Saudi Arabia. In spite of these pressures, the process is implemented à la Turkey in five Central Asian republics - Azerbaijan, Uzbekistan, Kazakhstan, Kyrgyzstan, and Turkmenistan - though not in Tajikistan. There the majority speaks Pharsi, it is culturally and linguistically akin to Iran, and is changing to Arabic lettering.

Naturally, the move is slow: choosing a national language is not easy in multilanguage areas. Russian objection is not a barrier: Moscow is unwilling to intensify the process of de-Russification, hence tends not to support the 10 million Russians in the diasporas in Central Asia who seek prevalence of the Russian language. Also, when Latinization started in Central Asia, there was not in Turkey even one Russian language institute that could help the Republics "deRussify" their languages: the disintegration of the Soviet Union had caught it, like so many others, unprepared. In time a few successes did take place: Turkmenistan tends to be a trilingual country with Turkmeni, Russian and English as official languages. For other republics the current switch to Latin alphabets is the third change in the twentieth century: at the beginning of the Soviet era Arabic script was replaced by the Latin alphabet, and in 1939 Stalin forced a 
second change, to Cyrillic letters. In both cases the aim was to promote unity and to isolate the Soviet Turkic republics from Iran, or from Turkey. ${ }^{51}$

\section{Iran and the Kurds}

One of the few things Iran and Turkey did agree upon was the need to preserve Iraq's integrity. With both countries supporting large ethnic minorities, Kurdish in Turkey's case, Kurdish and Azeri, in Iran's, neither had any doubt that partitioning Iraq on national-ethnic lines would undermine their own sovereign integrity. It was also why, loath to inflame their own minorities, they strongly objected to the formation of a Kurdish state. Yet despite this broad area of consensus, Iran and Turkey came close to blows over, on the one hand, Turkey's actions in the Kurdish "Safe Haven" in northern Iraq and, on the other, Iran's alleged support of the PKK.

Iran, as noted, took strong exception to Turkey's constant incursions into northern Iraq, which, it suspected, were designed to push Turkey eastwards at its expense. Ankara, on its part, accused Iran of cynically supporting the PKK, in return for a quiet life at home. Iran, while allowing its 4.5 million, mostly Sunni Muslim, Kurds a measure of cultural freedom - they were permitted to speak their own language and run their own television channels - nevertheless discriminated against them, so that the latter often strained against the Iranian bit. Consequently, there is no love lost and a great deal of friction between the Kurds and Tehran, who Iran utterly mistrusts, suspecting them of nursing nationalist sentiments. The last thing Iran wanted was for the PKK to extend its mandate into Iran, whipping up separatist feelings among its large and potentially dissident Kurdish community. Accordingly, Tehran reached an agreement with the PKK whereby the latter conceded that Iran's Kurdish community was off limits, while, in return, Iran allowed the PKK to rest and recoup on Iranian territory, on condition that the PKK did not launch attacks on Turkey from the 50 kilometer strip along the Iranian-Turkish Border. If this was not bad enough, Iran, Turkey accused, went well beyond the letter of the agreement, supplying the PKK with heavy arms and Katyusha rockets, some of which were used during an attack on a Turkish guard post in the Silopi district of Siyahkaya in January 1997. In 1998, following Syrian-Turkish anti-terrorist accord, which forced Syria to abandon the PKK, Iran, Ankara alleged, replaced Syria as the PKK's principal source of support. It allowed the PKK to establish camps in the Iranian villages along the Iranian-Turkish border and the Orumiyeh region. It provided the PKK with basic services and facilities as well as support. Wounded PKK guerrillas were treated in Iranian hospitals, while Iranian officials met with high-ranking PKK leaders, including Osman Ocalan, Abdullah Ocalan's brother. ${ }^{52}$

In the summer of 1999, Turkish jets, allegedly in pursuit of PKK guerrillas, attacked a base belonging to the Islamic Revolutionary Guards and an unidentified village near the town of Piranshahr in West Azerbaijan, along Turkey's 
southeast border. The attack was followed by a brief exchange of fire between the Turkish aircraft and Iranian ground forces. But this was a rare occurrence. Unlike northern Iraq, where Turkey felt free to take action against the PKK, Ankara was unwilling to attack the PKK's bases in Iran, as such action would almost certainly provoke an Iranian military response. Therefore, the Turkish army restricted its actions to bombing PKK positions along the Turkish-Iranian border. Similarly, other than to lodge some very strong protests, Turkey took no action to end against Tehran's links with the PKK. This was in marked contrast to Syria, who, smaller and weaker than Iran, was intimidated, threatened, and ultimately forced to sever all ties with the Kurdish terrorist organization. The risks of pursuing a similar policy with Iran were simply too great. ${ }^{53}$

Turkey and Iran found themselves supporting opposite sides in the early 1990s Azeri-Armenian war over the Nagorno-Karabakh enclave: Shi'ite Muslim Iran was siding with Christian Armenia, Turkey supported Azerbaijan. The area became a battlefield for possession between Armenians and Azeris as Soviet power crumbled in the late 1980s, after independence from Moscow rule. In 1991 Nagorno-Karabakh, an Armenian enclave inside neighboring Azerbaijan, unilaterally declared independence from Azerbaijan. The war that erupted caused at least 30,000 deaths and created a million refugees, mostly Azeri. Armenia won the war and still holds a quarter of Azerbaijan's territory.

Armenia was the only country among the former Soviet Republics with whom Turkey failed to establish diplomatic relations. This was hardly unexpected given that the Armenians and Turks have a long history of mutual antipathy and enmity. The Ottoman Empire had often discriminated against, and occasionally persecuted, its Christian Armenian subjects. The empire's alleged responsibility - a responsibility Turkey utterly denies - for the death of 1.5 million Armenians during the First World War became a running sore in Turkish-Armenian relations, which continued to fester, blighting their relations right up to the twenty-first century. In the 1990s, Turkey, with some reason, suspected Armenia of secretly supporting militant Armenian separatists, as part of its policy of Armenian irredentism. It further believed that extremist Armenian nationalist groups were closely cooperating with the PKK in order to destabilize Turkey. Armenia, also to Turkey annoyance, hoped to establish close military ties with two of Ankara's arch-rivals, Syria and Greece, with the aim of coordinating their actions should any one of the three find itself at war with Turkey. (Tozun Bahcheli writes that at most the Greco-Syrian accord was no more than an informal understanding allowing, perhaps, Greek warplanes to land in Syria in case of emergency, such as Turkish attacks on the Greek Cypriots). ${ }^{54}$

Turkey cautiously sided with the Azeris - it limiting itself mainly to training Azeri troops and handing them medical supplies. Of all the Central Asian Republics, Azerbaijan was the closest to Turkey. With strong ethnic and linguistic ties - Azeri is the Central Asian Turkic language most similar to Turkish - and a shared history - the Ottoman Empire had ruled parts of Azerbaijan - Ankara had a special interest in that country. Turkey was the first to recognize Azerbaijan, 
in 1991. Between 1991 and 1999, the two countries signed over 100 bilateral agreements, including trade and finance agreements, agricultural agreements, transport and telecommunication agreements, scientific agreements, health and social welfare agreements, and sporting and cultural agreements. Turkish construction companies signed contracts in Azerbaijan worth 2.5 billion dollars, equal, at least on paper, to what they earned in all the other Republics together. The Baku-Tiblisi-Ceyhan pipeline project to transport Caspian oil and gas to Turkey and Europe would, if realized, profit the partners to the deal to the tune of several billions of dollars a year. And this was only one of its many attractions, which included, among other things, the happy prospect of putting an end to Russia's monopoly over Central Asia's energy resources. Azerbaijan is looked upon as Turkey's closest partner in the Caucasus - most Azerbaijanis believe that Ankara is the only regional power with the will and ability to contain Russia's assertiveness. ${ }^{55}$

Admittedly, things did not always run smoothly. Ankara was unhappy at the Azeris' attempts to strike a balance between Russia, Iran and Turkey, while Baku worried that Turkey sought to carve itself too dominant a position in the country. But, on the whole, with Turkey looking upon Azerbaijan as its closest regional ally and the Azeris relishing Turkey's economic and other help and aware that Turkey was the only power capable of balancing even blocking Russia's invidious influence, it proved a warm and profitable relationship. The fact that both had a common enemy in Armenia served only to cement their relationship further.

Notwithstanding calls in Turkey for military activity, Turkey failed to come openly to the beleaguered Azeris' aid. Other than furnishing Baku with medical supplies, training Azeri troops, and offering some limited diplomatic support, it did nothing. This was partly because Turkey did not want, by siding with the Muslim Azeris against the Christian Armenians, to raise the specter of the historical Christian-Muslim rivalry. More importantly, it was also because Turkey hoped that by staying out of the conflict it would avoid a confrontation with Russia. Russia, who disliked Turkey's growing influence in the region, enjoyed a close relationship with Armenia, and had consistently backed it in the Nagorno Karabakh dispute. Any active Turkish intervention on the side of the Azeris would, Ankara feared, trigger an immediate Russian response, which might take one of several forms. Russia might decide to intervene in the war and, with several military bases in Armenia, it was much better placed to come to Armenia's aid than Turkey was to assist Azerbaijan. There was also the possibility that Turkish intervention would lead to open Turkish-Russian hostilities, something Turkey was particularly keen to avoid, especially with Russian troops patrolling the Turkish-Armenian and Turkish-Georgian borders. ${ }^{56}$

In its confrontation with Azerbaijan, Yerevan was supported by Russia and Iran, both objecting to the growing power of Turkey and pan-Turkism. This strange policy of Shi'ite Iran siding with the Christian Armenian enemies of Azeri Shi'ite Muslims - Azerbaijan is 70 percent Shi'ite - is understandable 
when people bear in mind the existence of a restless, nationally minded Azeri minority in Iran. Between 33 and 40 percent of the Iranians are of Azeri origin; other estimations are any number between 8 and 25 million. The existence in Baku of a strong pan-Azeri tendency for unity with the Azeris in Iran, explains the policy of Tehran. Actually, there are more ethnic Azeris living in Iran than in Azerbaijan. Iran is also the greatest exporter to Armenia, mainly food, manufactured goods and machinery, in addition to some 10 percent of Armenia's electricity demands. Iran, next to the CIS, is Armenia's biggest export market, mainly metals and building materials. ${ }^{57}$

Still, despite occupying opposite ends of the pole, politically, religiously and ideologically, and despite the fact that each threatens the other's identity, Ankara and Tehran have yet to engage in battle. Instead, the two have been content to limit themselves to exchanging, albeit very vicious, verbal and diplomatic blows, with occasional covert action. Turkey and Iran can point to the absence of any territorial controversies. Their common border has not been disputed for 400 years -one of the oldest borders in the world, demarcated in 1639 by an agreement between the Ottoman and Iranian empires. High-ranking officers from both armies who command the military units in the border area meet regularly, even in periods of tension and non-dialogue between the two states. Bilateral trade in 2001 reached 1.2 billion dollars, of which Iranian oil export to Turkey amounted to 700 million dollars. ${ }^{58}$ Officially, Iran is cautious not to support the PKK, lest this arouses its own 4.5 million Kurds -9 percent of the population - and Turkey accepts that Iranian Revolutionary Guards support the Kurdish underground or instigate Muslim radical terrorism in Turkey, not official government bodies in Tehran. It seems that fear of a crisis that would be disruptive to bilateral relations, causes Turkey to moderate its criticism against Tehran. And, as above, the different aggressive treatment Turkey assigns to Syria, smaller and weaker than Iran, demonstrates the caution she pursued with Iran - an ideological adversary and another supporter of the PKK. Risks are simply too high.

\section{Turkey-Syria: crises and rapprochement}

Iran probably fits The Economist's view of a country Turkey would love seeing moved elsewhere. ${ }^{59}$ Notwithstanding Syria becoming closer to being defined in similar words by Turkey, there has recently been a surprising development in Turkish-Syrian relations - surprising because, not long ago, Turkish newspapers were rejoicing at Damascus's calamity, announcing that "terror is in deep mourning." This was said following the death in June 2000 of the Syrian President, Hafez al-Assad. The presence of Ahmet Sezer, Turkey's President, at the funeral did not change the mood of the Turkish media but, explained a Turkish source, "miracles do happen and Assad's death and Turkish-Syrian relations is the same as happened to Stalin:" the Soviet dictator's death in 1953, signaled a 
new beginning in the superpowers' cold-war relations. Similar improvement took place between Damascus and Ankara. But before "the miracles," a different atmosphere predominated over the two countries' relations. Ankara was concerned lest Syria's peace negotiations with Israel, started in Madrid in October 1991, let alone a peace agreement, would remove Damascus from the list of nations supporting terrorism without Syria first withdrawing its assistance from the PKK. ${ }^{60}$ Moreover, Turkey feared that a Syrian-Israeli peace accord would make Damascus more powerful in its conflicts with Turkey: Damascus was probably interested in the peace talks with Israel to achieve the neutralization of the Israeli front. Syria could then cope successfully with its real if not existential problems - its water and territorial conflicts with Turkey. Sixty percent of the water supplied in Syria comes from the Euphrates River that originates in Turkey, and Syria strongly claims sovereignty to Alexandretta - since July 1939 the Turkish province of Hatay -persistently depicting the area as Syrian on its maps.

A major obstacle to the two countries' relations was removed in October 1998 when Abdullah Ocalan was expelled from Damascus. The bilateral trade for the year 1999 amounted to 539 million dollars - a decline from 615 million in 1998 - owing to global decrease in oil prices, in agriculture and because of a number of droughts. Syria still accounts for 1.3 percent of Turkey's total exports and 0.7 percent of total imports, i.e. third in the Middle East, after Israel and Egypt. Turkey exports synthetic materials, iron, steel, margarine, agricultural and automotive products, and imports mainly Syrian crude oil. Turkey plans to import 2 billion cubic meters of Syrian gas, but the two countries lack the finances needed to lay a gas pipeline. Ankara aims at a 1 billion dollar volume bilateral trade, and Damascus is looking for work permits for more Syrians in Turkey and for better cooperation over the water issue. Triple talks - Iraqi water experts joined Turkish and Syrian engineers - resumed recently over the Euphrates water. Ankara stresses that it gives Syria more water than Syria can handle or needs, yet is reluctant to commit itself concerning the future. "We can't guarantee that we'll be that benevolent for long," say Turkish officials. Such words do not raise optimism in Damascus, which is without water most nights. Still, a good omen for possible improved relations is Syria's readiness to alter the curriculum of Syrian schools so that the 500 years of Ottoman rule should not be regarded anymore as imperialism.

Syria suffers from a deep crisis: decline of oil prices - oil is 70 percent of Syria's exports - and of agriculture products, mainly cotton, created 12-15 percent unemployment that badly affected the Syrian stagnated economy. The 1997 Syrian GNP was less than 900 dollars per person (1,050 in 1995), and the Syrian annual population growth stood at 3.8 percent - among the highest in the Middle East - facts which do not ease economic and social strains. Interestingly, most Syrians do not have bank accounts and there is no private banking system in the country. With Syrian GDP down by 4.4 percent in 1997, GNP per person being less than 900 dollars, a sharp decline in foreign investments, in tourism, in remittances from Syrians working abroad, and in the output 
of the drought-ridden agriculture, improvement of contacts with Turkey was essential.

Turkish enthusiasm indeed increased: the Under Secretary for Foreign Trade, Kursat Tuzman, announced during a visit of Turkish businessmen to Damascus that, "When Turkey becomes a full EU member, the border of the Union will start from Syria." The Syrians, no less enthusiastic, reciprocated by promising Turkish businessmen the opportunity to reach Gulf markets through Syria. Syria looks for thriving contacts with Turkey, but the most astonishing move has been the cooperation between the two armies and the conclusion of military cooperation agreements, culminating in the overt visit of the Syrian Chief of Staff to Ankara in June 2002. There was no Syrian demand for Turkey to scale down its contacts with Israel. On the other hand, there was probably a Turkish request that the Arab press would tone down its objection to the Turkish-Israeli rapprochement. A number of editors of the Arab press are of Syrian origin and it looks as if they comply with a similar request from Damascus. Furthermore, the Turkish-Syrian military contacts - for example, mutual instruction of officers in both countries military academies, exchange of intelligence pertaining to the PKK, joint military exercises, the unearthing of mines along their common border, etc. - lessen the Syrian criticism aimed against similar interaction between Ankara and Israel. ${ }^{61}$

Syria is dependent on the Euphrates' uninterrupted flow. In addition, the "pincer-like" grip which Israel and Turkey exert on it, practically makes ineffective its ability to pose a real threat to Turkey. The expulsion of Ocalan and Damascus's disassociation from the PKK - Syria thus relinquishing the only leverage it has vis-à-vis Turkey - reveal an economically and militarily weak Syrian state. Unless water stops flowing - which might then produce desperate Syrian moves - one can expect a quiet Turkish-Syrian border. It is worth noting that this actual impotence on behalf of Syria has had its implications even on Athens. A Syrian state turning powerless vis-à-vis Turkey, affected the Greek decision to stop alienating Turkey and to start a dialogue with her (see Chapter 6.)

\section{The Turkic tribe: Turkey's relations with the Caucasian and Central Asian countries}

A most loaded issue - emotionally, culturally, politically, economically, and militarily - has been posed before Turkey in the 1990s: the resumption of contacts with its Caucasus and Central Asian kin. No other matter put a clearer question before the Turkish quest for identity. Ideas like pan-Turkism (Turkculkuk) and Turanism (Turanalik), which had laid dormant for years owing to the communist separation between Turkey and the "Outside Turks," or the "Captive Turks," or the "Brothers and Cousins," resurfaced. And while sincere intentions - even temptations - to deepen these contacts were high, the potential abandonment of the national Turkish way and the Western European wishes in favor of a 
non-defined, large Asian-Turkic frame, is problematic. Notwithstanding emotions and hopes, it seems that there will be no Turkic union or commonwealth led by Ankara - indeed, a suggestion to establish a "Turkic Commonwealth" was officially rejected in Ankara. ${ }^{62}$

Turkey's interests in good relations with the Caucasian and Central Asia countries seem to be obvious. Good relations with the Muslim republics, the special relations with Israel, a rapprochement with Russia - all serve as alternatives to the alienation Turkey faces in Europe. Suffice it to mention the importance of markets for Turkish goods and sources for energy needs among the producing countries around the Caspian Sea. Similarly, lessening the dependence on Arab energy by procuring oil and gas from the Central Asian markets is another incentive for good Turkish-Turkic interaction. Central Asia is of vital political and strategic importance for Ankara: it borders with Iran and Russia - two powers that want to exert their influence there, that want to resume their past hegemony, most likely on Turkey's expense. Turkey feels close, linguistically, culturally, and ethnically, to these countries. Turk Hava Yulari, the Turkish airline, has been for years the only foreign airline that served the Central Asian republics. British Airways, KLM, El-Al and Lufthansa, to mention but few, followed suit only later. Similarly, Turkish television broadcasts to almost all major cities there.

The affinity with the Turkic world - the six ex-Soviet Muslim republics plus the Turanian peoples, approximately 155 million people - plays a major role in the Turkish search for identity. The ideas of pan-Turkism and Turanism encompass the area from Azerbaijan to Xinjiang. It talks of the recreation of brotherhood and cooperation of the Turkic world, the one that predated the Ottoman Empire. Pan-Turkists frequently spoke and wrote of a Great Turkey, stretching from the Mediterranean nearly to the Pacific, or from the Adriatic to the Chinese Wall - "a powerful and affluent state, with its ancient glories restored and old customs revived." ${ }^{63}$ Others, aware of the political hurdles - for instance, the expression of pan-Turkic sympathies by Ankara might antagonize the host countries of Turkic minorities - merely canvass cultural and economic features or confine themselves to a smaller region that stretches up to the Caspian Sea. One way or another, this is something that strongly attracts many in Turkey.

The political influence and power of the pan-Turkist lobby in Turkey should not be exaggerated. Gareth Winrow attributed it to the small number of Turkish citizens who are recent immigrants from Central Asia. ${ }^{64}$ The threat of Turkish nationalism being swapped for something much larger is a hurdle the pan-Turkist lobbyists could hardly get over. This deprives the pan-Turkist groups of more extensive grassroots support. Also, since its inception, Kemalism tolerated cultural and economic cooperation among peoples of Turkic origin. Political unity among them - "Turanism" - something that directly contradicts the idea of Turkish nationalism of focusing only on Turks in Anatolia and on those left in Rumelia plus the Western and European notions of it, was not accepted. Turkish ideologists and politicians, among them the historian Zeki Velidi Togan (1890-1970), known for his work on the origins of Turkic clans in 
Russia and Central Asia, and Alparslan Turkes (1917-97), Deputy Prime Minister in the 1970s and Member of Parliament in the 1990s, were tried, sentenced and exiled for promoting Turanism. ${ }^{65}$

It should be recalled that Turan is an undefined area in the steppes of Central Asia. Its limits were given as China in the east, Tibet, India, and Iran in the south, and the Caspian Sea in the west and north. Turanism, as clearly explained by Jacob Landau, had as its chief objective rapprochement, and ultimately union, among all peoples whose origins are purported to extend back to Turan. Pan-Turkism strives for some sort of union - cultural, or physical, or both among all peoples of proven or alleged Turkic origins, whether living both within and without the frontiers of the Ottoman Empire, subsequently the Republic of Turkey. Turanism, thus, is a far broader concept than pan-Turkism, embracing such peoples as the Hungarians, the Finns and Estonians. ${ }^{66}$

Many Turks have viewed the Kemalist and communist imposed separation from the Turkic world as artificial, the resumption of contact as "homecoming." As such, these attitudes challenge the uniqueness of Turkish nationalism or the European-oriented Kemalist ideology. Turkey thus faces two "pans" that challenge Kemalism and its territorial Turkish nationalism: the ethnic pan-Turkism and pan-Islam. Externally and internally, the importance for Turkey of Central Asia and its links with the Muslim Caucasian and Asian republics (Azerbaijan in the Caucasus, Kazakhstan, Kyrgyzstan, Tajikistan, Turkmenistan and Uzbekistan in Central Asia, all independent since August-December 1991) is on par with the country's utmost and top issues. Some say that the country's soul is at stake. Similarly, the leaderships of these republics, eager to achieve international recognition and entry into economic and financial bodies, regarded Turkey as a model state "who has made it." A Muslim people living in a secular, Westernoriented state, has been an example that most Central Asian elites want to apply in their countries. Also, Turkey, a friend and ally of the Western countries, was perceived as an intermediary who could introduce these Asian republics to Western know-how, investment, assistance, and democracy.

Remarks made by Hikmet Cetin, Speaker of the Turkish Grand National Assembly, might add an interesting insight to our discussion. It links together EU alienation towards Turkey, anti-democracy, anti-modernism, and an implicit explanation of the increase of extreme ideas and ideologies in Turkey. Excessive Turkish nationalism, Muslim radicalism, and the search for alternatives, whether in the Caucasus, in the third world, among the Muslim peoples, etc. will affect the Turkic world as well. "Turkey's exclusion from the EU will send a negative message to the Muslim-majority states of Central Asia, discouraging them from continuing along the path of democratization and modernization," warned Cetin. ${ }^{67}$

Ankara reveals an interest in Uzbekistan, Kazakhstan, and Turkmenistan the first for its geopolitical and military strength and importance, all the three for their oil, gas and raw materials that could be exported to Europe via Azerbaijan and the Turkish Mediterranean coast. Turkish entrepreneurs will thus gain rich contracts, a limit will be put to the number of supertankers 
crossing the Bosporus and Canakkale (Dardanelles) Straits, and apparently Turkish - not Russian - political, economic and cultural influences will prevail in these countries. As for the rest then, as noted, the Persian-speaking Tajikistan inclines toward Iran, in Kyrgyzstan priority is given to China, and in Kazakhstan Russian influence is clear.

Turkey has been instrumental in promoting regional multilateral schemes for economic, financial, scientific, technology and cultural cooperation. The idea was to promote contacts among states and peoples; some even envisioned the creation of a Turkic world commonwealth, bank and a common market. Summit conferences were convened; as it turned out Russian, not Turkish, was the lingua franca at these assemblies. Numerous meetings were held, and a plethora of correspondence and documentation were exchanged. The Turkish International Cooperation Agency (TICA) was established in 1992 to facilitate the activities of Turkish businessmen in Central Asia and to coordinate between Turkey and the Turkic states in such spheres as banking, training officials and establishing computer networks, etc. The agency helped organize the "Turkish Speaking" conferences of youth leaders, university sectors, and news agencies. The Turkish Ministry of Culture formed the Turkic Cultures and Arts Joint Administration. The Directorate of Religious Affairs of Turkey organized the Muslim leaderships of twenty-eight Turkic countries and communities, and launched the Eurasian Islamic Council Organization. None of the above has yet materialized to the extent its initiators wished. The Turkish International Cooperation Agency's success was not great, and cooperation remained mainly at the bilateral level, on occasions solely restricted to cultural and educational matters. It was found that each of the Turkic Muslim republics was moving down a separate path. When the Turkish Ministry of Education regarded the Turkic world as homogeneous and wanted to standardize school history textbooks throughout the Turkic states, it faced opposition from the Central Asian republics: they preferred history textbooks reflecting their own particular experience. ${ }^{68}$

Existing ethnic, border and religious conflicts, regional rivalries (for instance, Uzbekistan v. Kazakhstan), uneven economic development, different expectations, conflicting interests and influences, language and bureaucratic hurdles - all detrimentally affected the establishment of a Turkic world extending from the Mediterranean to China. The aforementioned Turkish model that has not yet fully proven itself in Turkey itself - a secular, liberal democracy with a free market economy has little applicability to the Caucasus or Central Asian republics. As was shown by Gareth Winrow, high budget deficits, rising foreign debts, poor taxation systems, strongman rule, lack of free, open, and competitive elections, censorship, bureaucratic inertia, corruption, nepotism, local disputes, etc., all impair democratization, hinder the development of economic and political reforms, in short reducing to the minimum the chances of success of the so-called Turkish model. Neither language affinity eased the process or produced the expected proximity: beyond the Caspian there is little in common between local populations and Turks. The Turkish language helps in Azerbaijan and 
Turkmenistan. In Kazakhstan Turks will be linguistically challenged. In Kyrgyzstan and Uzbekistan Turkish will be completely useless. Most of these places were never part of the Ottoman world, so there is little in the way of shared culture beyond the Caspian Sea. ${ }^{69}$

Only small amounts of monies, from the Turkish business community and Western sources, were invested in Central Asia or the Caucasus; money was assigned instead to Russia. The lack in Central Asia of proper physical and financial infrastructure and distribution channels, vital for the conduct of business, was detrimental to increasing economic relations. No wonder Ankara's trade with the Turkic peoples accounted in 1998 for not more than 3.5 percent of its exports and a mere 1 percent of its imports.

Above all, Central Asians express strong reluctance to antagonize either the large Russian communities that live within the Central Asia republics, or Moscow, who sees itself as the successor of the Soviet Union in Central Asia. Also, Iran harbors some hegemonic ambitions and it objects to manifestations of excessive Turkish influence or Turkish secularism. Caution has led the Central Asians to refrain from crowning Turkey as the new patron. The ex-Soviet Muslim republics refused to accept a new yoke, to bind themselves exclusively to Turkish leadership or to Turkic formations, only a few years after they got rid of Soviet supervision and Moscow-controlled bureaucracies. The republics seek instead to diversify their relations, rather than becoming identified with this or that model. Gareth Winrow mentions that in the euphoric days of the early 1990s, when the Turkic republics secured independence from Moscow, President Ozal had hoped to announce the creation of a Turkic Common Market and establishment of a Turkic Trade and Development Bank. As noted, nothing materialized, among other reasons because of the Turkic leaders' reluctance to secure only Turkic political and economic support, solely from within the Turkic world. ${ }^{70}$

In spite of apparent familiarity with local culture that was supposed to grant Turkish businessmen an advantage compared with their Western counterparts, Charalambos Tsardanidis points to the Turks' lack of adequate knowledge, if not ignorance, as to the real situations, differences and wishes of the peoples and republics of Central Asia. This, he says, is a result of decades of separation between Kemalist Turkey and the republics becoming communist. Thus, many Turks went to Central Asia in the 1990s with the expectation of discovering people like themselves, and were surprised to meet total strangers. All this proved stronger than the unrealistic visions of a Turkey-led Turkic world, or, as Gregory Gleason puts it, the Central Asians began to think of Turkey only as a partner, not a model, nor a leader. ${ }^{71}$

There are also good reasons that prevent Turkey from becoming too involved in these republics, especially with those with whom it has ethnic ties. Ankara was unable to provide aid to the Central Asian countries in the quantities hoped for. The 1.5 billion dollar commercial credit offered to these countries by Turkey's Eximbank for the purchase of Turkish goods and foodstuffs 
and for the building of infrastructure, covered only a fraction of these countries' needs. Surprisingly, parts of the credit were not used; unsurprisingly, the borrowers often failed to make repayments. It turned out that some Turkish goods, for instance basic medical equipment, were too sophisticated to be installed in Central Asia or the Caucasus. Also, as noted, to avoid confrontation with Russia, Turkey wisely decided to refrain from interfering in the Armenian-Abzerbaijani conflict over Nagorno-Karabakh. On her part, Moscow did not conceal her objection to the sale of American F-16 fighter aircraft assembled in Turkey, to the modernization of Turkey's Black Sea navy, and to the Turkish army getting equipped with best of US armaments. It seems that the Moscow-Turkey interaction is more important to Turkey than any far-fetched and dubious panTurkism in the Caucasus and Central Asia. The Turks are also aware that the Central Asia leaders wish to remain part of a loose Russian security umbrella in order to check the spread of religious Muslim radicalism. Derogatory references were made to "Wahhabism" in Uzbekistan, i.e. to the puritanical brand of Islam common in Saudi Arabia. Neither are the Turkish armed forces in a position to help contain Muslim extremism emanating from Tajikistan's civil war or Afghanistan's Taliban. Russia seems more capable and ruthless. ${ }^{72}$

Turkey's decision to keep out of the cruel ethnic conflicts in the Caucasus and Central Asia - "an ethnic time-bomb," according to Jacob Landau - has something to do with the position of the republics themselves as well. As mentioned before, having only recently been liberated from the domination by the Soviets, they could hardly be interested in exchanging it for domination by the Turks, who are equal in population to the six Muslim republics combined. By successfully removing the Soviet economic monopolies, the Muslim republics, for economic interests, are reluctant to install Turkish monopolies. They encourage, instead, the involvement of Russians and Turks together in economic and trade projects and ventures. Some of the republics find difficulties with pan-Turkism. Kazakhstan, for instance, a republic of minorities, is inclined to promote a policy of pan-Kazakhism, rather than pan-Turkism: it encourages expatriate Kazakhs to return home, in order to alter the demographic balance. ${ }^{73}$

The republics' needs are estimated in the range of 250 billion dollars. Since Russia is in no position to support them economically, the republics turn for assistance elsewhere, to places like Europe, the United States, Japan and China. However, the West, although regarded as an ideal model, is remote - culturally and geographically - and it will not invest its monies in the risky economies of Central Asia. Turkey and Iran are therefore approached to serve as a model in the solution of pressing problems. Ankara lacks the sources to provide the republics with their major economic, social or material needs, but it helps educate Central Asian diplomats, offers modest credits and financial aid, assists with plans for setting up local air companies, and has invited 10,000 Central Asian students and 4,000 military cadets to study and train in Turkey's universities and war colleges. 
Ankara circulates its newspapers and publications in the Muslim republics, harboring hopes to make Turkish the lingua franca of the area, and as mentioned previously, helps in the Latinization of the republics' languages. Turkey also assisted in rebuilding the republics' telephone, computer, television and satellite communication systems, cut by Moscow in 1992 after the republics proclaimed their independence. Turkey is also perceived as helping the American cause in Central Asia - presenting a model of Western democracy and of "sane" Islam in contrast to Russia or Iran - and as capable of bringing US economic and financial support there. Indeed, Turkish influence in Central Asia will be more credible if in its wake Western businessmen show up. ${ }^{74}$

Turkey's dilemma, though not simple, has apparently been resolved. The continuation of Kemalism, the territorial Turkish nationalism - which rejected the ethnic unity of the Turkic peoples, i.e. pan-Turkism or the more embracing Turanism - may well result in the abandonment of the peoples of Central Asia to Russian hegemony or Iranian Shi' ism. On the other hand, a major involvement would mean giving up of the dream of the Western alternative - something Turkey's enemies in Europe and the West's enemies in Turkey would welcome. By concentrating on the nebulous and potentially dangerous Asian option, Ankara would have to relinquish that special Turkish nationalism which has been built up with so much effort over the last seventy-five years. "We are not going to build an Eastern alternative" declared President Demirel, emphasizing the direction Turkey had no intention of taking. ${ }^{75}$ Still, frictions, alienation, exclusion, criticism, patronizing, suspension, rebukes, sanctions, etc., that too often mar Turkey's relations with the "Big West" - Europe, EU, USA, etc. - arouse the following reaction:

Turkish culture is very different from the West. Concepts such as strong family ties, respect for elders and unconditional love of and commitment to children sound like cliches in the West but form the basis of Turkish society. Loneliness is a rare phenomenon. Relationships are not based on manipulation, and the foremost motivation of individuals is not greed. The people of Turkey are enamored of foreigners, and racism seems to be distant from everyone's mind, even though the West tries to portray Turks as ogres... On the political side, Turkey could slowly but politely let Europe stand on the sidelines while the republic looks to itself, to its other friends and to the Turkic nations of Asia. We are culturally more akin to them than to the West, with its excessive and exploitative nature, or to the Arabs, with their strange views of women and their theocratic political systems. Turkish culture, since its origins on the steppes, has always put women on the same horse as men. ${ }^{76}$

Each of the conclusions of this quotation, presented so unequivocally, could be subject to fierce attacks, if not total refutation. Neither is the call for the "Turkicness" of Turkey as a substitute for Westernization the prevailing theme in the country. Even ardent supporters of pan-Turkism would agree that Central Asia's Tajikistan, Kirgistan, and Uzbekistan could not be Turkey's source for modernization, democracy, prosperity, etc. Neither would the country's pan-Islamists consider Yemen, Mauritania, or Bangladesh to be the wish of Turkey. They all 
know very well that twenty-first century Turkey should look to the West. In addition, becoming Turkic, means becoming embroiled in the Caucasus and Central Asian interstate and ethnic conflicts, as well as arousing Russia's wrath. Hitherto, Turkey has managed to avoid this kind of excessive involvement and Kemalism, with its European, Western, and secular orientation, seems to prevail. But pan-Turkism and pan-Islam do show the alternatives, as does the too frequent European and Western alienation that creates the mindset to produce suggestions like those in the above quotation.

\section{General elections, 18 April 1999}

Nationalism, Islam, the Turkic peoples, relations with the West, the PKK, forcing Syria to its knees - these and other issues of nation and identity aspects eventually reflected in the Turkish general elections of April 1999. Weak coalition governments shuffled in and out of office in Turkey during the 1990s. The average rate was one per year. Eleven governments, including nine coalitions, held office in Ankara during the decade. Major policy changes in Turkey were thus most unlikely, because only a strong government could undertake bold policy departures. ${ }^{77}$ Erbakan's government was no exception: it ruled for less than a year. A rather unexpected coalition with Tansu Ciller, who enjoyed support from the Turkish media and business community as well as Western leaders, did not remove military pressure from the government. Morton Abramowitz's description of the Erbakan-Ciller cooperation reflected the surprise:

Turkey's political system breeds political promiscuity. Over the years ... party leaders have jumped into bed with some strange partners. The current government is provocative even for Turkey: a 70 year old devout Muslim leading a religious party ... [who] shares power with the female, U.S. trained leader of a center-right secular party whom many Turks believe is corrupt. ${ }^{78}$

Erbakan had to resign following Turkey's Chiefs of Staff's charges that he acted against the secular character of Turkey. His Welfare Party was later dissolved for similar accusations, and he was banned from taking part in future political activities. Ciller's shield did not help Erbakan: it turned out to be that Ciller herself cooperated with Erbakan just to stop the Welfare Party's investigations against her being allegedly involved in huge financial vice. ${ }^{79}$

Mesut Yilmaz's minority government replaced that of Erbakan. Yilmaz captured the leadership of his Motherland Party in 1991 and 1997 was in his third stint as Prime Minister (two months in 1991, three in 1996). His government consisted of the Motherland Party, of Bulent Ecevit's center-left Democratic Left Party, and defectors from the True Path Party. For its majority in parliamentary votes, the government relied on Deniz Baykal's Republican People's Party. ${ }^{80}$ However, Yilmaz's government lost its parliament majority in November 1998, only seventeen months after it came to power. The reason? Although considered 
"clean" among often corrupt competitors, Yilmaz found himself entangled in a similar manner to Ciller, namely, grave suspicion of silencing investigations or covering state-Mafia organized crime triangle, and personally being involved in corruption. His November 1998 fall, after seventeen months in power, brought about the transition government led by Ecevit and the elections of April 1999.

The April elections showed that the electorate found the Welfare Party and later the Virtue Muslim Party to be successful in providing running water, collecting the garbage and providing services, and consequently kept them in control of municipal administrations. The same electorate, however, did not hesitate to reflect in the ballot boxes that they were not satisfied with Muslim parties' politics in state affairs. Radical and protest voting in 1999 did not increase Islamic power but, rather, and dramatically so, the nationalist view. The Milliyetci Hareket Partisi (MHP), the Nationalist Action Party, became the second largest political party represented in parliament, with 18.1 percent of the vote. Ecevit's Demokratik Sol Partisi (DSP), the Democratic Left Party, came first with 21.6 percent of the vote, the Muslim Virtue Party (Fazilet Partisi or the FP) headed by Recai Kutan won 15.5 percent, Mesut Yilmaz's Anavatan Partisi (ANAP), the Motherland Party, achieved 13.4 percent, and Tansu Ciller's True Path Party (Dogru Yol Partisi) got 12.3 percent of the vote.

The MHP, led by Devlet Bahceli, Ankara's Gazi University economics professor, enjoyed the frustration and patriotic pride of the Turkish electorate. The latter felt alienated, hence highly nationalist, as a result of the EU December 1997 Luxembourg decision to defer the negotiations on Turkey's accession into the EU; and the capture of Abdullah Ocalan, February 1999, only added to the excessive nationalist feelings. On such occasions the national or Turkic world options thrive and reflect in the ballots. Turks, sensing their growing economy and military prowess, as well as close links with the United States and Israel, and living in a country that emerges as the regional power which forces its will on its neighbors (Greece, Syria), expressed their pride in the ballots. Hurriyet's Enis Berberoglu gave the following explanation of MHP's victory: "The coffins of the soldiers martyred in the Southeast, being sent to their hometowns for burial, have obviously helped boost the MHP vote. While the DSP and the FP received votes by inspiring hope, the MHP has received votes by demanding 'Let us hang APO [Abdullah Ocalan] "." ${ }^{81}$ It should be mentioned that the same MHP had failed to enter parliament in the general elections of 1995 because it could not pass the 10 percent threshold. The MHP election triumph was doubly important because the party had undergone serious internal upheaval following the death of its legendary leader, Alparslan Turkes.

Ecevit's DSP was also seen as a nationalist force because of the party's and its leader's positions on specific issues - support for Turkish Cyprus, strong opposition to the PKK, to Kurdish nationalism, the capture of Abdullah Ocalan, and so on. The party's support of the "Turkey First" approach ("Turkey First" has been a vague expression for the 1990s tendency to pursue a more active place for Turkey in regional and world affairs, a status that should match the country's 
importance and achievements) had also granted it a nationalist tone. The MHP's nationalism is more all-embracing - romantic, ideological, and ethnically based, with an emphasis on the wider "Turkish Nation," the pan-Turkish world comprising Turkey and the Turkic peoples, and Turkic parts of the former Soviet Union, of Cyprus, of the Balkans, and the Turkomans in the Middle East. All this is an "indispensable part of Turkey's national interests," according to the MHP's election program. In order to achieve these ambitious objectives, the MHP found it necessary to establish a "Ministry of the Turkish World," and to set up a "Common Market of the Turkish World."

Following the general elections of April 1999, Bulent Ecevit, Prime Minister for the fifth time, found, together with Bahceli's MHP and Yilmaz's Motherland Party, a common national ground and formed a coalition government. Ecevit had to choose between Ciller and Yilmaz. The two - both leading centerright parties but lacking any real ideology difference, hence vying for the same electorate, hence the extreme personal hatred that they feel towards each other - had to separate. Ciller went to the opposition, together with the Muslim Virtue Party. This was not an exception: Turkish politics is often explained more by personal likes and hatreds than by differences of substance or ideology.

Forming the fifty-seventh government of the Republic of Turkey - there were six governments in Turkey during the previous five years - the three-party coalition seemed to have introduced a measure of political and economic stability. The election to the presidency of Ahmet Necdet Sezer, the Constitutional Court Chief Justice (May 2000), raised hopes for further democratization, respect for human rights, and corruption-free government. The capture of Ocalan and, in practice, the ending of the fifteen-year war with the PKK, were expected to help in the fight against inflation, to ease the privatizing of various sectors of the Turkish economy, and in attracting foreign investment. To improve the chances of economic stability, Turkey won the confidence of the International Monetary Fund and other financial bodies and received multibillion dollar loans to sustain its monetary system.

Ecevit's government has also intended to toughen Turkey's foreign policy and strengthen its military. The fact that Turkey was left with only one conflict and with only Greece as an adversary - precisely because of this solitude Athens opted for negotiations with Turkey (see Chapter 7) - could be attributed to Ankara's unyielding military deterrence and its prudent foreign policy. No doubt the end of the Turkish-PKK war and Ankara desisting from the implementation of the death penalty on Abdullah Ocalan, eased the EU decision to invite Turkey to join its ranks.

\section{Notes}

1 Ayse Kadioglu, "The Paradox of Turkish Nationalism and the Construction of Official Identity," Middle Eastern Studies, Vol. 32, No. 2, April 1996, Special Issue on Turkey: Identity, Democracy, Politics, p. 186. 
2 Dogu Ergil, "Identity Crises and Political Instability in Turkey," Journal of International Affairs, Vol. 54, No. 1, Autumn 2000, pp. 43-62, 50.

3 M. Hakan Yavuz, "Cleansing Islam from the Public Sphere," Journal of International Affairs, Vol. 54, No. 1, Autumn 2000, pp. 21-42, 24.

4 Nicole Pope and Hugh Pope, Turkey Unveiled: A History of Modern Turkey, Woodstock and New York, Overlook Press, 1997, p. 17.

5 Ergil, "Identity Crises and Political Instability in Turkey," p. 50.

6 TDN, 1 December 1997.

7 Mete Tuncay, TDN, 4 March 1999.

8 For Islam in Turkey see: Morton I. Abramowitz, "Dateline Ankara: Turkey after Ozal," Foreign Policy, No. 91, Summer 1993, pp. 176-177; The Economist, 14 December 1991; 27 February 1993; Dankwart A. Rustow, Turkey: America's Forgotten Ally, New York, Council on Foreign Relations, 1987, p. 33; Richard Tapper, "Introduction," in Richard Tapper (ed.), Islam in Modern Turkey, London and New York, Tauris, 1991, pp. 9-12, 14, 17-20; Feroz Ahmad, The Making of Modern Turkey, London, Routledge, 1993, pp. 220-223; Jeremy Salt, "Nationalism and the Rise of Moslem Sentiment in Turkey," Middle Eastern Studies, Vol. 31, No. 1, January 1995, pp. 13-27; G. Bechor, Ha'aretz, 3 February 1993; G. Zohar, Ha'aretz, 20 June 1993; Ha'aretz, reprinted from New York Times, 9 March 1995; Ely Karmon, "Radical Islamic Political Groups in Turkey," MERIA Journal, Vol. 4, article 2, 9 February 1998.

9 Kadioglu, "The Paradox of Turkish Nationalism and the Construction of Official Identity," p. 190.

10 Abramowitz, "Dateline Ankara," pp. 176-177; Time, 19 October 1992; Yoav Karni, Ha'aretz Supplement, 9 August 1991; G. Bechor, Ha'aretz, 3 February 1993; Daily Telegraph, 2 August 1996; Ha'aretz, 17 June 1998; George E. Gruen, "Defining Limits on Religious Expression in Public Institutions: The Turkish Dilemma," paper submitted to the Jerusalem Center for Public Affairs Summer Workshop, 1998, on "Religion in the Public Sphere," p. 11.

11 Henry J. Barkey, “ The Struggles of a 'Strong' State," Journal of International Affairs, Vol. 54, No. 1, Autumn 2000, pp. 87-105, 103.

12 Philip Robins, Turkey and the Middle East, London, Royal Institute of International Affairs and Pinter Publishers, 1991, pp. 39-41; Tapper, Islam in Modern Turkey, pp. 9, 12.

13 Rustow, Turkey: America's Forgotten Ally, p. 33.

14 Tapper, Islam in Modern Turkey, pp. 14-23; G. Bechor, Ha'aretz, 3 February 1993; G. Zohar, Ha'aretz, 20 June 1993; Gruen, "Defining Limits on Religious Expression in Public Institutions," p. 12.

15 Abramowitz, "Dateline Ankara," p. 175; Ha'aretz, 31 August 1993; Ha'aretz, reprinted from New York Times, 9 March 1995; Gruen, "Defining Limits on Religious Expression in Public Institutions," p. 12.

16 Resat Kasaba and Sibel Bozdogan, "Turkey at the Crossroad," Journal of International Affairs, Vol. 54, No. 1, Autumn 2000, pp. 1-20; Nulifer Gole, quoted in Jolyon Naegele, “Turkey: Military Upholds Secularist Tradition," MERIA Seminar: REF/RL Magazine: Turkey Military Upholds Secularist Tradition, 5 August 1998.

17 Kasaba and Bozdogan, "Turkey at the Crossroad", 7.

18 The Economist, 14 December 1991; 27 February 1993; Rustow, Turkey: America's Forgotten Ally, pp. 34-36.

19 Ergil, "Identity Crises and Political Instability in Turkey," p. 50.

20 M. Hakan Yavuz, "Cleansing Islam from the Public Sphere," Journal of International Affairs, Vol. 54, No. 1, Autumn 2000, pp. 21-42, 39; Kasaba and Bozdogan, "Turkey at the Crossroad," p. 17; Stephen Kinzer, New York Times, 17 January 1998.

21 Philip Robins, Turkish Foreign Policy under Erbakan," Survival, Vol. 39, No. 2, Summer 1997, pp. 84, 85. On the brutal attacks of Erbakan on Israel during his 1970s and 1980s 
opposition days, see Alon Liel, Turkey in the Middle East: Oil, Islam, and Politics, Boulder, CO, Lynne Reinner, 2001, pp. 206-208; The Economist, 30 May 1998.

22 Ha'aretz, 24, 25 September 1996.

23 Time, 21 October 1996.

24 Abdullah Gul, quoted in Scott Peterson, Christian Science Monitor, 20 January 1998.

25 Yavuz, "Cleansing Islam from the Public Sphere," p. 39.

26 Andrew Mango, "Reflections on the Ataturkist Origins of Turkish Foreign Policy and Domestic Linkages," in Alan Makovsky and Sabri Sayari (eds), Turkey's New World: Changing Dynamics in Turkish Foreign Policy, Washington, DC, Washington Institute for Near East Policy, 2000, p. 14; The Economist, 12 October 1996.

27 Yavuz, "Cleansing Islam from the Public Sphere," pp. 21-42; Meyron Rapoport, Yediot Ahronot (Hebrew), 23 February 1996; Morton I. Abramowitz, "This, Too, Will Pass," Newsweek, 11 November 1996. Abramowitz served in Ankara from 1989 to 1991.

28 Atila Eralp, "Turkey and the European Union in the Post-Cold War Era," in Alan Makovsky and Sabri Sayari (eds), Turkey's New World: Changing Dynamics in Turkish Foreign Policy, Washington, DC, Washington Institute for Near East Policy, 2000, p. 179.

29 Mango, "Reflections on the Ataturkist Origins of Turkish Foreign Policy and Domestic Linkages," p. 16.

30 Andrew J. A. Mango, “Testing Time in Turkey," Center for Strategic and International Studies and the Massachusetts Institute of Technology, Washington Quarterly, Vol. 20, No. 1, Winter 1997, pp. 3-20; Robins, "Turkish Foreign Policy Policy under Erbakan," pp. 90-91; Bulent Aras, "Further Comments on Turkey-Iran", MERIA Turkeylist, 7 September 1999.

31 Brent Sasley, "Turkey Energy Politics in the Post-Cold War Era," MERIA Journal, Vol. 2, No. 4/Sasley: Turkey Energy Policy, 8 December 1998; Necdet Pamir, "The Future Prospects of the Euroasian Corridor: Is There a Future?" Paper presented at the conference on "Building a Secure Euroasia in the 21st Century," Istanbul, 8-9 June 2000; Laurent Ruseckas, "Turkey and Eurasia: Opportunities and Risks in the Caspian Pipeline Derby," Journal of International Affairs, Vol. 54, No. 1, Autumn 2000, pp. 217-236, 229.

32 Yavuz, "Cleansing Islam from the Public Sphere," pp. 21-42.

33 James Kitfield, "The Turkish Model," National Journal, Vol. 34, No. 9, March 2002, pp. 598-608.

34 Laura Kay Rozen, Christian Science Monitor, 8 April 1998.

35 Ibid.

36 Muharrem Kayhan, Chairman of TUSIAA, The Washington Institute's Policy Forum, Washington, DC, 19 November 1997.

37 Chicago Tribune, 10 April 1998; Sami Kohen, "Torn Over Garments, Turkey Hurtles Toward a Showdown," Christian Science Monitor, 25 March 1998.

38 Gole, quoted in Naegele, "Turkey: Military Upholds Secularist Tradition;" Ustun Reinart, "Freedom under Wraps: Islamic Garb on Turkish Campuses," MERIA Journal, Vol. 2, No. 3, Palestinian and Turkish Women, 16 September 1998. Ustun Reinart sees a feminism struggle in the use of head covers for women. The scarf or the veil guards against intruding eyes of men and serves as a sign that the women's first allegiance is to God, not to their husbands or fathers. Stephen Kinzer, "Mayor Guilty of Godliness: What Next for Turkey?" reprinted from the New York Times, MERIA Seminar: Kinzer on Turkey, 7 October 1998; Gruen, "Defining Limits on Religious Expression in Public Institutions," p. 12.

39 Abdullah Gul, member of the Refah and a former minister of state, quoted in Scott Peterson, Christian Science Monitor, 20 January 1998. The Fazilet banner shows a crescent, five light rays and a beating heart. The five principles of the party read: Demokrasi, Insan Haklari, Ozgurluk, Hukuk Devleti, Kalkinma (Democracy, Human Rights, Freedom, State 
of Law, Development). See also "Virtue Party Launches Webpage," MERIA Seminar, 26 July 1998.

40 Ergil, "Identity Crises and Political Instability in Turkey," pp. 43-62.

41 Ahmad, The Making of Modern Turkey, p. 221.

42 The Economist, reprinted in Ha'aretz, 19 December 1996; 29 April 1997; 17 August 1997; 20 August 1997; Time, 12 January 1998; Turkish Probe, 30 November 1997.

43 TDN, 19 April 1999.

44 Ibid.

45 Tapper, Islam in Modern Turkey, pp. 3, 10-11, 21, 22; Bernard Lewis's introduction to Rustow's, Turkey: America's Forgotten Ally, pp. vii-xi; Sami Zubaida, “Turkish Islam and National Identity," Middle East Report, No. 199, April-June 1996, pp. 10-15, 12; Karmon, "Radical Islamic Political Groups in Turkey;" Emmanuel Sivan, "Why Radical Muslims Aren't Taking over Governments," MERIA Journal, Vol. 2, No. 2, Item 2 of 8, Sivan on Revolutionary Islam, 24 May 1998; Barry Rubin, "Islamic Radicalism in the Middle East: A Survey and Balance Sheet," MERIA Journal, Vol. 2, No. 2, Article 3 of 8, Rubin on Islamic Political Movements, 27 May 1998.

46 TDN, 4 March 1998.

47 Karmon, "Radical Islamic Political Groups in Turkey", Sabah, 21 December 1996; Ha'aretz, 22 December 1996; Gruen, "Defining Limits on Religious Expression in Public Institutions," p. 29.

48 Karmon, "Radical Islamic Political Groups in Turkey."

49 Kemal Kirisci, "Turkey and the Muslim Middle East," in Alan Makovsky and Sabri Sayari (eds), Turkey's New World: Changing Dynamics in Turkish Foreign Policy, Washington, DC, Washington Institute for Near East Policy, 2000, p. 51.

50 Jacob M. Landau, Pan-Turkism. From Irredentism to Cooperation, Bloomington, IN, and Indianapolis, IN, Indiana University Press, 1995, p. 200.

51 Toby Lester, "New Alphabet Disease?," Turkistan Newsletter, BITIG: Vol. 8:13/03, January-March 1998; Nadir Devlet, Director, The Turkic Studies Institute, Marmara University, Istanbul, interview, TDN, 12-13 April 1999.

52 Milliyet, 28 July 1999; Hurriyet, 29 July 1999; TDN, 25 July 1999. Sometimes in 2000, the Turkish government paid an undisclosed sum as compensation to the families of seven Iranians killed in the Turkish airforce attack on the village near the Iranian town, Piranshahr. See Arabies Trends, January 2001, p. 20.

53 M. Hakan Yavuz, "Describing Turkish Foreign Policy towards Iran," Draft, 31 March 1998; Hurriyet, 18 October 1999.

54 Tozun Bahcheli, "Turkish Foreign Policy toward Greece," in Alan Makovsky and Sabri Sayari (eds), Turkey's New World: Changing Dynamics in Turkish Foreign Policy, Washington, DC, Washington Institute for Near East Policy, 2000, p. 139.

55 Suha Bolukbasi, "Ankara's Baku-Centered Transcaucasia Policy: Has It Failed?, Middle East Journal, Vol. 51, No. 1, Winter 1997, p. 92.

56 Time, 19 October 1992; 20 November 1995; Ha'aretz, 16 June 1992; 10 July 1995; Der Spiegel, reprinted in Ha'aretz, 30 June 1992.

57 Turkistan Newsletter, Vol. 98-2:030, 17 February 1998; Landau, Pan-Turkism, p. 197; Gareth M. Winrow, Turkey and the Caucasus: Domestic Interests and Security Concerns, London, Royal Institute of International Affairs, 2000, pp. 8-11.

58 Turkish Radio Hour, 22 June 2002.

59 The Economist, "Survey Turkey", 8 June 1996.

60 Ha'aretz, 12 January 2001. On 8 October 1997 the US Administration designated thirty foreign groups as being "Terrorist Organizations." Among them the Algerian Armed Islamic Group (GIA), the Lebanese Hizbullah, the Egyptian Gamaat Al-Islamiya, the Egyptian Al-Jihad, the Jewish organization Kach, the Jewish organization Kahane Chai, the Iranian Mujahideen E-Khalk, the Turkish Kurd PKK, the Turkish Revolutionary 
People's Liberation Party/Front (DHKP/C), the Islamic Movement of Uzbekistan, and seven Palestinian organizations. MERIA Seminar, 24 October 1997.

61 Hurriyet, 9 May 2000; Hurriyet, 10 May 2000; Milliyet, 10 March 2000; TDN, 23 March 1999; Ha'aretz, 19 March 2002; Oguz Celikkol, Turkish Under Secretary of State for Middle Eastern Affairs, lecture, Ankara, the Middle East Technical University, 12 May 1999. For details about Syrian economy see Ha'aretz, 2 April 1999 and CIA World Fact Book, quoted in Ha'aretz, 14 December 2000.

62 William Hale, Turkish Foreign Policy, 1774-2000, London, Frank Cass, 2000, p. 292.

63 Landau, Pan-Turkism, pp. 187, 194.

64 Gareth M. Winrow, "Turkey and the Newly Independent States of Central Asia and the Transcaucasus," MERIA Journal, Vol. 2, No. 5, 15 June 1997.

65 For the idea of Turanism see Hugh Poulton, Top Hat, Grey Wolf and Crescent. Turkish Nationalism and the Turkish Republic, London, Hurst, 1997, pp. 82-84.

66 Landau, Pan-Turkism, p. 1. Another example - in addition to Turanism, pan-Turkism, etc. - that strove to direct Turkey from its traditional Western aspirations, was "Third Worldism.” It was canvassed by Mumtaz Soysal, Turkey's Foreign Secretary (1994), a constitutional law expert who turned popular columnist. It did not result in the expulsion of Soysal (as had happened to Turkes and Togan), but neither did he remain in office long enough to bring any lasting change. See Winrow, "Turkey and the Newly Independent States of Central Asia and the Transcaucasus."

67 Hikmet Cetin, Speaker of the Turkish Grand National Assembly, Washington, DC, the Washington Institute's Policy Forum, 5 May 1998.

68 Winrow, "Turkey and the Newly Independent States of Central Asia and the Transcaucasus."

69 The Economist, "Survey Turkey," 8 June 1996; Gareth M. Winrow, Turkey and the Caucasus: Domestic Interests and Security Concerns, p. 7.

70 Winrow, "Turkey and the Newly Independent States of Central Asia nd the Transcaucasus."

71 Charalambos Tsardanidis, "Turkey and the Central Asian Republics" (draft title), 1999; P. Carley, "Turkey and Central Asia: Reality Comes Calling," in Alvin Z. Rubinstein and Oles M. Smolansky (eds), Regional Power Rivalries in the New Euroasia: Russia, Turkey and Iran, New York, M. E. Sharpe, 1996, p. 190; Gregory Gleason, The Central Asian States Discovering Independence, Boulder, CO, Westview, 1997, p. 147.

72 Tsardanidis, "Turkey and the Central Asian Republics," The Economist, 4 July 1998.

73 Landau, Pan-Turkism, pp. 198, 200.

74 Ibid., pp. 209-210, 212.

75 Yoram Bronovski, Ha'aretz, 3 April 1992; Ekavi Athanassopoulou, "Turkey and the Black Sea Initiative," in Theodore A. Couloumbis, Thanos M. Veremis and Thanos Dokos (eds), The Southeast European Yearbook, 1993, Athens, Greece, The Hellenic Foundation for European and Foreign Policy (ELIAMEP), 1994, pp. 38; Guardian, 23 November 1992.

76 Birsan Iskenderoglu, “Turkey vs. the West," TDN, 20 February 1999.

77 Bahcheli, "Turkish Foreign Policy toward Greece," p. 147.

78 Morton Abramowitz, “This, Too, Will Pass," Newsweek, 11 November 1996.

79 On corruption investigations against Ciller see Zeyno Baran, "Corruption: The Turkish Challenge," Journal of International Affairs, Vol. 54, No. 1, Autumn 2000, pp. 127-146, 136.

80 Alan Makovsky, “A Euro-Battered Mr. Yilmaz Comes to Washington,” Washington Institute, Policywatch, Vol. 291, 18 December 1997.

81 Hurriyet, 19 April 1999.

82 Sibel Utku, TDN, 21 April 1999; Harun Kazaz, TDN, 22 April 1999. 